\title{
Acute Respiratory Distress Syndrome in Cancer Patients
}

\author{
Alisha Y. Young and Vickie R. Shannon
}

\section{Contents}

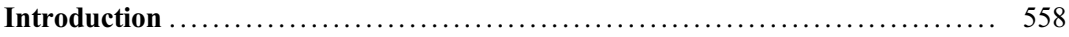

Definition and Pathogenesis of ALI and ARDS $\ldots \ldots \ldots \ldots \ldots \ldots \ldots \ldots \ldots \ldots \ldots \ldots$

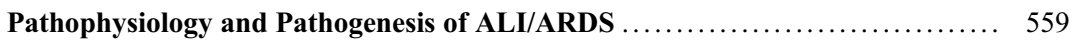

Etiology and Predisposing Factors of ARDS in the Cancer Patient ............ 562

Primary and Secondary Triggers of ALI/ARDS in the Cancer Patient ........ 565

Pneumonia/Opportunistic Infections ................................. 565

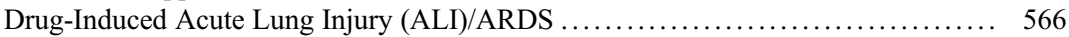

Postoperative ARDS .............................................. 567

ALI/ARDS Post Hematopoietic Stem Cell Transplant ....................... 568

ALI/ARDS Due to Pulmonary Spread of Tumor: Lymphangitic Carcinomatosis

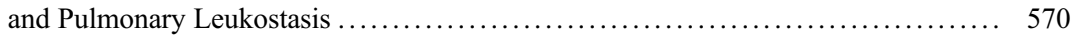

Clinical Presentation and Diagnostic Workup of ALI/ARDS ............. 571

Cancer-Related ALI/ARDS: Outcomes and Treatment ................ 572

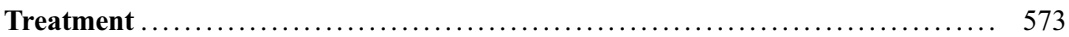

Pharmacologic Therapies ......................................... 573

Noninvasive and Invasive Ventilation ................................ 574

Sedation and Neuromuscular Blockade .............................. 576

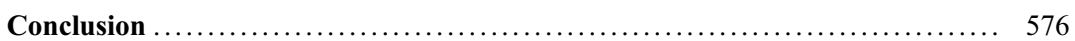

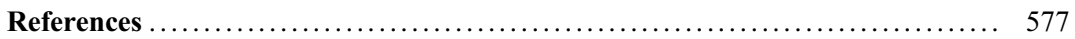

A. Y. Young

Department of Pulmonary Medicine, University of Texas at McGovern Medical School, Houston, TX, USA

\section{R. Shannon $(\bowtie)$}

Department of Pulmonary Medicine, Division of Internal Medicine, The University of Texas at MD Anderson

Cancer Center, Houston, TX, USA

e-mail: vshannon@mdanderson.org

\section{Abstract}

Acute respiratory distress syndrome (ARDS) is a heterogeneous form of acute, diffuse lung injury that is characterized by dysregulated inflammation, increased alveolar-capillary interface permeability, and non-cardiogenic pulmonary edema. In the general population, the incidence and mortality associated with ARDS over the last two decades have steadily declined in parallel with optimized approaches 
to pneumonia and other underlying causes of ARDS as well as increased utilization of multimodal treatment strategies that include lungprotective ventilation. In the cancer settings, significant declines in the incidence and mortality of ARDS over the past two decades have also been reported, although these rates remain significantly higher than those in the general population. Epidemiologic studies identify infection, including disseminated fungal pneumonias, as a major underlying cause of ARDS in the cancer setting. More than half of cancer patients who develop ARDS will not survive to hospital discharge. Those who do survive often face a protracted and often incomplete recovery, resulting in significant long-term physical, psychological, and cognitive sequelae. The residual organ dysfunction and poor functional status after ARDS may delay or preclude subsequent cancer treatments. As such, close collaboration between the critical care physicians and oncology team is essential in identifying and reversing the underlying causes and optimizing treatments for cancer patients with ARDS. This chapter reviews the diagnosis and common causes of ARDS in cancer and gives an update on the general management principles for cancer patients with ARDS in the ICU.

\section{Keywords}

Acute respiratory distress syndrome

Malignancy $\cdot$ Pulmonary $\cdot$ Lung injury ·

Pneumonia $\cdot$ Mechanic ventilation $\cdot$ Intensive care unit

\section{Introduction}

Acute respiratory distress syndrome (ARDS) is a heterogeneous form of acute, diffuse lung injury that is characterized by dysregulated inflammation, increased alveolar-capillary interface permeability, and non-cardiogenic pulmonary edema. In the general population, the incidence and mortality associated with ARDS over the last two decades have steadily declined in parallel with optimized approaches to pneumonia and other underlying causes of ARDS as well as increased utilization of multimodal treatment strategies that include lungprotective ventilation. In the cancer setting, significant declines in the incidence and mortality of ARDS have also been reported, although these rates remain significantly higher than those in the general population. Epidemiologic studies identify infection, including disseminated fungal pneumonias as a major underlying cause if ARDS in the cancer setting. More than half of cancer patients who develop ARDS will not survive to hospital discharge. Those who do survive often face a protracted and frequently incomplete recovery, resulting in significant long-term physical, psychological, and cognitive sequelae. The residual organ dysfunction and poor functional status after ARDS may delay or preclude subsequent cancer treatments. As such, close collaboration between the critical care physicians and oncology team is essential in identifying and reversing the underlying causes and optimizing treatments for cancer patients with ARDS.

\section{Definition and Pathogenesis of ALI and ARDS}

In 1965, Asbaugh and colleagues described 12 adult patients who developed diffuse pulmonary opacities, refractory hypoxemia, tachypnea, and tachycardia following acute medical illness or surgical trauma. At autopsy, prominent hyaline membranes lining the alveoli were seen. This syndrome was initially coined as adult respiratory distress syndrome and later renamed acute respiratory distress syndrome (ARDS) to emphasize the acuity of the syndrome and to include pediatric-aged patients with similar clinical and histopathologic findings [1].

In its original definition, the diagnosis of ARDS was established based on findings of a rapidly progressive respiratory failure that evolves over a 2-day period and results in respiratory distress, severe arterial hypoxemia, and the need for mechanical ventilation. Multiple definitions of ARDS have been proposed since the original description by Asbaugh. In 1994, the American-European Consensus Conference 
(AECC) expanded the definition to include an arterial partial pressure of oxygen to fraction of inspired oxygen $\left[\mathrm{PaO}_{2} / \mathrm{FIO}_{2}\right]$ of $\leq 200 \mathrm{~mm} \mathrm{Hg}$ ) with bilateral infiltrates on frontal chest radiograph, and no evidence of left atrial hypertension. The AECC also recognized a less severe form ARDS, referred to as acute lung injury (ALI), which used similar ARDS criteria but with milder hypoxemia $\left(\mathrm{PaO}_{2} / \mathrm{FIO}_{2}<300 \mathrm{~mm}\right.$ $\mathrm{Hg})$ [2]. Although this definition of ARDS was widely adopted, criteria lacked explicit definitions for "acute." Furthermore, interobserver interpretations of chest radiographs were highly variable, and ventilator settings such as PEEP and/or $\mathrm{FIO}_{2}$ render $\mathrm{PaO}_{2} / \mathrm{FiO}_{2}$ ratios inconsistent. Spurred by issues regarding the lack of a clear definition of ARDS, experts from the European Society of Intensive Care Medicine (ESICM), joined by the American Thoracic Society (ATS) and the Society of Critical Care Medicine (SCCM), were empaneled to create an ARDS definition task force [3]. Out of these meetings emerged the 2012 Berlin definition of ARDS. This definition defines "acute" as the at-risk period for the development of ARDS, which was designated as within 7 days of the original insult. The experts also proposed three mutually exclusive categories of ARDS, based on the degree of hypoxemia: mild (200 $\mathrm{mmHg}>\mathrm{PaO}_{2} / \mathrm{FIO}_{2}<300 \mathrm{mmHg}$ ), moderate $\left(100 \mathrm{mmHg}-\mathrm{PaO}_{2} / \mathrm{FIO}_{2}<200 \mathrm{mmHg}\right)$, and severe $\left(\mathrm{PaO}_{2} / \mathrm{FIO}_{2}<100 \mathrm{mmHg}\right)$. The panel retained the requirements of bilateral pulmonary infiltrates consistent with pulmonary edema as defining criteria for ARDS and added chest computed tomography (CT) as a potential imaging tool. Comparisons of ARDS definitions based on AECC and Berlin criteria are shown in Table 1. An expanded definition of ARDS, proposed by Murray, classifies patients according to the severity of lung injury, associated clinical disorder(s), and the presence of nonpulmonary organ dysfunction. In this definition, lung injury severity is stratified according to the extent of abnormalities on chest radiographs, degree of hypoxemia, respiratory system compliance, and PEEP requirements, using the lung injury scoring system [4].

\section{Pathophysiology and Pathogenesis of ALI/ARDS}

ALI/ARDS is marked by three sequential phases, each characterized by different clinical, histopathologic, and radiographic manifestations. In the acute exudative phase, damage to the pulmonary epithelial and endothelial surfaces triggers a cascade of events in the evolution of ALI/ARDS. The loss of integrity of the epithelial and endothelial barriers that ensues results in extravasation of a protein-rich edema fluid into the alveolar space. This form of increased permeability pulmonary edema is commonly referred to as primary or noncardiogenic pulmonary edema and has as its histopathologic hallmark the accumulation of a proteinaceous fluid in the interstitium as a result of breach of the integrity of the alveolar and microvascular barriers within the lungs. Inflammatory cells, including neutrophils, red blood cells, platelets, and fibrin, are also prominent features of the edema fluid which flood alveoli, creating large areas of ventilation-perfusion inequality or shunt formation. Widespread but patchy areas of destruction to alveolar type I epithelial cells, which are exquisitely sensitive to this type of lung injury, are a common early histologic finding. Type II pneumocytes are also injured, which results in disruption of normal epithelial ion transport activity, reduced surfactant turnover, and, consequently, reduced clearance of edema fluid from the airway. Loss of normal surfactant activity by activated polymorphonuclear neutrophils and plasma proteins also contributes to microatelectasis and shunt formation. Impaired epithelial cell ion transport further compounds efficient clearance of edema fluid from the distal airways. The precipitated plasma proteins, fibrin, and necrotic debris form hyaline membranes. Hyaline membranes along with marked hyperplasia of cytologically bizarre and pleomorphic type II pneumocytes are key components of diffuse alveolar damage (DAD), the histopathologic hallmark of ARDS [2, 5-8]. These physiologic changes promote decreased lung compliance and subsequent respiratory failure, characterized physiologically by severe ventilation/perfusion (V/Q) mismatching and marked refractory hypoxemia. The 
Table 1 Evolution of ALI/DADS definition

\begin{tabular}{|c|c|c|c|}
\hline & Ashbaugh & $\begin{array}{l}\text { American-European } \\
\text { Consensus Conference } \\
\text { (AECC) }\end{array}$ & Berlin \\
\hline Year & 1967 & 1994 & 2012 \\
\hline $\begin{array}{l}\text { ARDS } \\
\text { description }\end{array}$ & $\begin{array}{l}\text { Rapidly progressive } \\
\text { respiratory failure associated } \\
\text { with noncardiogenic } \\
\text { pulmonary edema } \\
\text { (permeability pulmonary } \\
\text { edema) and severe hypoxemia; } \\
\text { PCW }<18 \text { mm Hg or no } \\
\text { clinical evidence of left atrial } \\
\text { hypertension }\end{array}$ & $\begin{array}{l}\text { Rapidly progressive respiratory } \\
\text { failure associated with } \\
\text { noncardiogenic pulmonary } \\
\text { edema (permeability } \\
\text { pulmonary edema) and severe } \\
\text { hypoxemia; PCW } \\
\text { measurements not required; } \\
\text { hydrostatic edema excluded via } \\
\text { other clinical clues }\end{array}$ & $\begin{array}{l}\text { Rapidly progressive respiratory } \\
\text { failure not explained by cardiac } \\
\text { failure or volume overload and } \\
\text { occurring within } 1 \text { week of the } \\
\text { triggering event }\end{array}$ \\
\hline $\begin{array}{l}\text { Definition of } \\
\text { "Acute" }\end{array}$ & $\begin{array}{l}\text { "Acute" without further } \\
\text { definition }\end{array}$ & $\begin{array}{l}\text { "Acute" without further } \\
\text { definition }\end{array}$ & $\begin{array}{l}\text { Onset within } 1 \text { week of a } \\
\text { known clinical insult or new or } \\
\text { worsening respiratory } \\
\text { symptoms }\end{array}$ \\
\hline \multirow[t]{4}{*}{$\begin{array}{l}\text { ARDS } \\
\text { stratification }\end{array}$} & \multirow[t]{4}{*}{ None specified } & \multirow[t]{4}{*}{$\begin{array}{l}\text { Any patient with } \mathrm{PaO}_{2} / \mathrm{FIO}_{2} \\
<200\end{array}$} & $\begin{array}{l}\text { Three mutually exclusive } \\
\text { subgroups identified based on } \\
\mathrm{PaO}_{2} / \mathrm{FIO}_{2} \text { and PEEP } \\
>5 \mathrm{~mm} \mathrm{Hg}\end{array}$ \\
\hline & & & $\begin{array}{l}\text { Mild: } 200 \mathrm{mmHg}>\mathrm{PaO}_{2} / \\
\text { FIO }_{2}<300 \mathrm{mmHg}\end{array}$ \\
\hline & & & $\begin{array}{l}\text { Moderate: } 100 \mathrm{mmHgPaO}_{2} / \\
\text { FIO }_{2}<200 \mathrm{mmHg}\end{array}$ \\
\hline & & & $\begin{array}{c}\text { Severe: } \mathrm{PaO}_{2} / \\
\mathrm{FIO}_{2}<100 \mathrm{mmHg}\end{array}$ \\
\hline $\begin{array}{l}\text { Oxygen/ } \\
\text { PEEP } \\
\text { specifications }\end{array}$ & $\begin{array}{l}\text { None specified, other than } \\
\text { hypoxemia requiring } \\
\text { oxygenation }\end{array}$ & $\begin{array}{l}\text { Arterial partial pressure of } \\
\text { oxygen to fraction of inspired } \\
\text { oxygen } \mathrm{PaO}_{2} / \mathrm{FIO}_{2}<200 \mathrm{~mm} \\
\mathrm{Hg}) \text {, regardless of PEEP }\end{array}$ & $\begin{array}{l}\text { Stratified according to PEEP or } \\
\text { CPAP requirements: mild, } \\
\text { PEEP or CPAP }<5 \mathrm{mmHg} \text {; } \\
\text { moderate or severe, PEEP } \\
>5 \mathrm{~cm} \mathrm{H}_{2} \mathrm{O}\end{array}$ \\
\hline Risk factors & None specified & None specified & $\begin{array}{l}\text { Pneumonia, sepsis, trauma } \\
\text { pancreatitis; echocardiography } \\
\text { recommended to exclude } \\
\text { hydrostatic edema if no risk } \\
\text { factor identified }\end{array}$ \\
\hline $\begin{array}{l}\text { ALI } \\
\text { designation }\end{array}$ & ALI not recognized & $\begin{array}{l}\text { Same as ARDS except } \mathrm{PaO}_{2} / \\
\mathrm{FIO}_{2}<300 \mathrm{~mm} \mathrm{Hg}\end{array}$ & $\begin{array}{l}\text { ALI category removed from } \\
\text { definition }\end{array}$ \\
\hline
\end{tabular}

$A L I$ acute lung injury, $\mathrm{PaO}_{2}$ partial pressure of oxygen, $\mathrm{FIO}_{2}$ fraction of inspired oxygen, $\mathrm{PEEP}$ positive end-expiratory pressure

inhomogeneous lung injury pattern is marked by perfused alveoli which are not adequately ventilated (physiologic shunt), while others are ventilated but not adequately perfused (dead space).

Increased permeability pulmonary edema may also occur in the absence of DAD and is referred to as capillary leak syndrome. In the cancer setting, this type of pulmonary edema typically occurs following the administration of cytokines such as $\mathrm{IL}_{2}$ and TNF, which disrupt the capillary endothelial cell integrity [9]. Both of these drugs may also cause direct toxicity to the myocardium, resulting in mixed or overlap edema associated with normal and increased permeability etiologies. Neurogenic and re-expansion pulmonary edema represent two other causes of mixed edema, which are frequently observed in the cancer setting.

Lung injury may resolve after the exudative stage or progress through the proliferative phase to the final stage of fibrosing alveolitis. The proliferative phase of ARDS typically occurs 7-14 days after the triggering insult. During this 
phase, exuberant proliferation of type II cells, fibroblasts, and inflammatory cells and regeneration of epithelial cells occur in an attempt to reestablish alveolar barrier function and repair the damaged alveolar structures. Therapeutic measures, such as oxygen toxicity, may promote further lung injury during this phase of ARDS. The proliferative phase is marked by minimal edema fluid and abnormalities of coagulation, which may give rise to extensive microvascular microthrombi and disruption of the pulmonarycapillary bed. Subsequent elevations in pulmonary vascular resistance may be significant enough to induce cor pulmonale in some patients. An extensive neutrophil-predominant alveolitis on BAL fluid and histopathologic findings of bizarre-shaped cuboidal type II alveolar cells are common findings [10]. Fever, leukocytosis, diminished systemic vascular resistance, and diffuse areas of alveolar and interstitial consolidation on chest radiographs may mimic clinical infection/sepsis during this phase, although an infectious cause is rarely found.

The final fibrotic phase is heralded by extensive collagen deposition into the alveolar, vascular, and interstitial beds, which irreversibly obliterate the airspace and small vessels, and further promotes dead space ventilation, shunt formation, and pulmonary hypertension refractory hypoxemia $[2,11]$.

Activation of the innate immune response, including neutrophils, complement and humoral inflammatory mediators, is thought to play a key role in the development of DAD in ARDS. This leads to a cascade of events, including the production of the Toll-like receptors on lung epithelial cells and activation of neutrophils and alveolar macrophages. The activated alveolar macrophages trigger additional immune responses, including cytokine production, which damage the alveolar-capillary interface and cause leakage of proteinaceous fluid into the alveoli, leading to the clinical manifestations of ARDS. Earlier studies suggested that neutrophilic inflammation was central to the development of ARDS. However, ARDS may develop in patients with profound neutropenia. Furthermore, stimulation of neutrophil production with granulocyte colony- stimulating factor does not appear to trigger or worsen ARDS in most patients. These observations imply that neutrophilic inflammation occurs as a consequence rather than a cause of ARDS and suggest that additional mechanisms of acute lung injury may be important. A role for proinflammatory cytokines in the initiation and/or amplification of the inflammatory response in ARDS is suggested by increased levels of macrophage inhibitory factor, tumor necrosis factor (TNF- $\alpha$ ), and interleukin-8 (IL-8) in the airways of patients with lung injury. Anti-inflammatory activities of tumor necrosis factor receptor (TNFr), interleukin-1 receptor antagonist (IL-1r), interleukin-10 (IL-10), and interleukin-11 (IL-11) have been shown to modulate the development of ALI/ARDS. Alterations in the delicate balance between pro- and anti-inflammatory cytokines in the airway likely play a critical role in ALI/ARDS development and offer therapeutic strategies in the management of this disorder $[4,10,12]$. Accumulating evidence increasingly implicates platelet activation in ARDS pathogenesis and suggests that these cells are pivotal in a host of inflammatory effects that contribute to ARDS development, including increased endothelial barrier permeability and augmented neutrophil recruitment into the airways [13]. These observations have laid the groundwork for ongoing studies to investigate the role of antiplatelet therapy in ARDS [14-16].

The majority of patients with clinical risk factors for ARDS do not develop ARDS. Thus, genetic susceptibility is thought to play a key role in the pathogenesis of this disorder. More than 40 candidate genes have been linked to ARDS risk, including the genes encoding angiotensin-converting enzyme (ACE), IL-10, tumor necrosis factor (TNF), vascular endothelial growth factor (VEGF), and LRRCI6A [17, 18]. Several molecular and immune biomarkers are being developed to identify distinct ARDS phenotypes. Although many of these biomarkers are currently in experimental stages of development, they hold promise in their potential for risk stratification of patients for ARDS and also in their ability to predict clinical outcomes [19-21]. For example, higher plasma levels of inflammatory biomarkers have been demonstrated 
in patients with a hyperinflammatory ARDS phenotype. This subgroup of patients may have a higher prevalence of sepsis and vasopressor use and require longer periods on the ventilator than their non-hyperinflammatory counterparts [22]. Elevated levels of specific inflammatory cytokines, such as TNF- $\alpha$, IL-1B, IL-6, and IL-8, have been shown to correlate with lung injury severity and may predict unfavorable outcomes, particularly among patients in which elevated biomarkers occur early and persist throughout the course of ARDS [22, 23].

\section{Etiology and Predisposing Factors of ARDS in the Cancer Patient}

Cancer patients are susceptible to a variety of overlapping ARDS risk factors including primary lung insults (pneumonia, aspiration, surgical and nonsurgical chest and/or lung trauma) and secondary sources of injury (drug toxicity, polytrauma, pancreatitis, hypertransfusion, sepsis, or septic shock that originates from extrapulmonary infections or noninfectious etiologies) (Table 2). For example, cancer-related primary insults, such as increased susceptibility to pneumonia or the propensity to aspirate, may be compounded by a variety of malignancy-related secondary issues, including toxicity from pneumotoxic drugs, blood/blood product transfusions, or sepsis. Major categories of risk factors that account for most of the reported cases of ALI/ARDS include infection, sepsis, chemotherapeutic agents (including molecular targeted therapies and immune-modulating agents), trauma, and aspiration of gastric contents. Radiation toxicity, tumor lysis syndrome, and leukoagglutinin reactions have also been linked to ARDS in patients with cancer. These conditions may act synergistically to increase the risk of ALI/ARDS. In a study by Pepe and colleagues, ARDS risk increased by 3.2fold among patients with three or more risk factors versus a single risk factor (85\% versus $25 \%)$ [24]. Traditional widely held beliefs purported that specific lung injury triggers have no bearing on clinical expression of ARDS or disease progression, which are primarily dictated by the severity of the lung insult and efficacy of the therapeutic intervention. Recent studies have questioned the validity of support for concepts that suggest that the clinical and histopathologic features of ARDS are identical, regardless of etiology. These investigations have identified a differential effect of ARDS on lung compliance and responsiveness to positive end-expiratory pressures (PEEP), with more severe reductions in compliance and decreased responsiveness to PEEP, ventilatory recruitment maneuvers, prone positioning, and other adjunctive therapies among patients with primary causes of ARDS versus extrapulmonary (secondary) etiologies [25, 26]. Reduced respiratory compliance and response to positive end-expiratory pressure (PEEP) may correlate with a higher prevalence of lung consolidation in patients with primary ARDS as opposed to prevalent edema and alveolar collapse associated with secondary forms of the disease [27]. This distinction may be clinically important. The concept of ARDS as a heterogeneous disorder may offer more precise clinical management. However, frequent overlapping pathogenetic mechanisms and morphologic alterations often render distinctions between primary and secondary forms of ARDS imprecise, and the concept of treatment approaches based on etiology of ARDS remains controversial.

Severe ARDS represents a classic example of lung failure whereby associated ventilation/perfusion abnormalities, shunts, or alterations of alveolar-capillary diffusion lead to pure hypoxia, at least in its early stages. By contrast, primary failure of alveolar ventilation, or pump failure, leads to severe hypercapnia and acidosis with only mild hypoxemia (Fig. 1). Impairments to any component of the ventilatory pump, including the respiratory muscles, central nervous system, and peripheral nervous systems, may lead to pump failure. Cancer and its treatment may adversely affect all components of the respiratory pump. For example, increased resistance loads due to tumors within the lung may cause intrinsic or extrinsic obstruction of the large airways, bronchospasm associated with certain chemotherapeutic agents, or concomitant COPD, and obstructive sleep apnea associated with head and neck tumors are 
Table 2 Common triggers of ALI/ARDS in cancer

\begin{tabular}{|c|c|c|c|c|}
\hline & $\begin{array}{l}\text { Clinical clues/risk } \\
\text { factors }\end{array}$ & $\begin{array}{l}\text { Clinical features and } \\
\text { imaging findings }\end{array}$ & Diagnostic testing & Treatment \\
\hline $\begin{array}{l}\text { Infection/ } \\
\text { pneumonia }\end{array}$ & $\begin{array}{l}\text { Productive cough, } \\
\text { pleuritic pain, fever, } \\
\text { chills, shortness of } \\
\text { breath }\end{array}$ & $\begin{array}{l}\text { Pulmonary infiltrates } \\
\text { may be lobar, multi- } \\
\text { lobar, diffuse, or bilateral } \\
\text { areas of consolidation } \\
\text { and/or ground-glass } \\
\text { change. Air } \\
\text { bronchograms may be } \\
\text { seen }\end{array}$ & $\begin{array}{l}\text { Gram stain/cultures } \\
\text { obtained on sputum or } \\
\text { bronchoscopically; } \\
\text { blood cultures; WBC } \\
\text { may be elevated, } \\
\text { normal, or decreased }\end{array}$ & $\begin{array}{l}\text { Antibiotics, supportive } \\
\text { care, ventilatory support, } \\
\text { as indicated }\end{array}$ \\
\hline Aspiration & $\begin{array}{l}\text { Witnessed aspiration or } \\
\text { high risk for aspiration; } \\
\text { bronchial erythema, } \\
\text { food, lipid-laden } \\
\text { macrophages seen on } \\
\text { bronchoscopy; } \\
\text { low-grade fever }\end{array}$ & $\begin{array}{l}\text { Infiltrates on chest } \\
\text { imaging usually } \\
\text { involving dependent } \\
\text { pulmonary segments }\end{array}$ & $\begin{array}{l}\text { Presumptive diagnosis } \\
\text { with negative cultures }\end{array}$ & $\begin{array}{l}\text { Supportive, ventilatory } \\
\text { support; supplemental } \\
\text { oxygen, antibiotics }\end{array}$ \\
\hline Pancreatitis & $\begin{array}{l}\text { Presence of risk factors - } \\
\text { gallstones, drugs/ } \\
\text { alcohol, viral infection. } \\
\text { Persistent abdominal } \\
\text { pain, nausea/vomiting; } \\
\text { elevated amylase and } \\
\text { lipase, with or without } \\
\text { abnormal imaging }\end{array}$ & $\begin{array}{l}\text { Dyspnea due to } \\
\text { diaphragmatic } \\
\text { inflammation/ARDS; } \\
\text { unexplained } \\
\text { hypotension }(5-10 \%) ; \\
\text { small pleural effusions }\end{array}$ & $\begin{array}{l}\text { Elevated lipase, } \\
\text { amylase }\end{array}$ & $\begin{array}{l}\text { Supportive; IV fluid } \\
\text { resuscitation, antibiotics, } \\
\text { ventilatory support, } \\
\text { oxygen, vasopressor } \\
\text { support, dietary } \\
\text { modifications, remove } \\
\text { offending drugs }\end{array}$ \\
\hline TRALI & $\begin{array}{l}\text { History of transfused } \\
\text { blood products within } \\
6 \text { h of clinical signs/ } \\
\text { symptoms: dyspnea, } \\
\text { hypoxemia, fever, } \\
\text { hypotension, cyanosis }\end{array}$ & $\begin{array}{l}\text { Bilateral pulmonary } \\
\text { infiltrates with normal } \\
\text { cardiac silhouette }\end{array}$ & $\begin{array}{l}\text { Diagnosis of exclusion; } \\
\text { infiltrates, hypoxemia } \\
\text { occurring within } 6 \mathrm{~h} \text { of } \\
\text { blood/blood product } \\
\text { transfusion that meets } \\
\text { criteria for ARDS is } \\
\text { designated transfusion- } \\
\text { related ARDS; exclude } \\
\text { hemolytic transfusion } \\
\text { reactions }\end{array}$ & $\begin{array}{l}\text { Supportive: oxygen } \\
\text { supplementation, } \\
\text { noninvasive respiratory } \\
\text { support with continuous } \\
\text { positive airway pressure } \\
\text { (CPAP) or bi-level } \\
\text { positive airway pressure } \\
\text { (BiPAP) may be } \\
\text { sufficient in less severe } \\
\text { cases, endotracheal } \\
\text { intubation with invasive } \\
\text { mechanical ventilation if } \\
\text { severe }\end{array}$ \\
\hline $\begin{array}{l}\text { Sepsis/ } \\
\text { shock }\end{array}$ & $\begin{array}{l}\text { Fever, hypotension, } \\
\text { lactic acidosis, DIC; } \\
\text { infectious source not } \\
\text { identified in all cases; } \\
\text { CRP > } 2 \text { SD above } \\
\text { normal; plasma prolactin } \\
\text { >2 SD above normal; } \\
\text { thrombocytopenia; CBC } \\
\text { may demonstrate } \\
\text { leukocytosis, } \\
\text { leukopenia, or normal } \\
\text { WBC with bandemia }\end{array}$ & $\begin{array}{l}\text { Signs/symptoms of } \\
\text { organ damage: nephritis, } \\
\text { transaminitis, adrenal } \\
\text { insufficiency, altered } \\
\text { mental status }\end{array}$ & $\begin{array}{l}\text { Appropriate clinical } \\
\text { context and positive } \\
\text { cultures }\end{array}$ & $\begin{array}{l}\text { Supportive; IV fluid } \\
\text { resuscitation, antibiotics, } \\
\text { ventilatory support, } \\
\text { oxygen, vasopressor } \\
\text { support }\end{array}$ \\
\hline HSCT & History of HSCT & $\begin{array}{l}\text { Variable, diffuse } \\
\text { infiltrates, nodules, } \\
\text { consolidation; evidence } \\
\text { of graft-versus-host } \\
\text { disease (allogeneic } \\
\text { transplants) }\end{array}$ & Diagnosis of exclusion & $\begin{array}{l}\text { Supportive; antibiotics } \\
\text { ventilatory support, } \\
\text { oxygen, vasopressor } \\
\text { support }\end{array}$ \\
\hline
\end{tabular}


Table 2 (continued)

\begin{tabular}{|c|c|c|c|c|}
\hline & $\begin{array}{l}\text { Clinical clues/risk } \\
\text { factors }\end{array}$ & $\begin{array}{l}\text { Clinical features and } \\
\text { imaging findings }\end{array}$ & Diagnostic testing & Treatment \\
\hline $\begin{array}{l}\text { Drug } \\
\text { toxicity }\end{array}$ & $\begin{array}{l}\text { History of exposure to } \\
\text { offending agent or } \\
\text { radiation; BAL may } \\
\text { demonstrate nonspecific } \\
\text { findings of predominant } \\
\text { lymphocytosis, } \\
\text { eosinophils, or foamy } \\
\text { macrophages, depending } \\
\text { on the suspected culprit }\end{array}$ & $\begin{array}{l}\text { Bilateral subpleural } \\
\text { reticulation; ground- } \\
\text { glass changes or } \\
\text { consolidation }\end{array}$ & $\begin{array}{l}\text { Diagnosis of exclusion, } \\
\text { lung biopsy } \\
\text { occasionally helpful }\end{array}$ & $\begin{array}{l}\text { Discontinue offending } \\
\text { agent; supportive care, } \\
\text { antibiotics, ventilatory } \\
\text { support, oxygen, } \\
\text { vasopressor support }\end{array}$ \\
\hline $\begin{array}{l}\text { Thoracic } \\
\text { surgery }\end{array}$ & $\begin{array}{l}\text { History of surgery, } \\
\text { intraoperative } \\
\text { ventilation, } \\
\text { intraoperative } \\
\text { transfusion }\end{array}$ & $\begin{array}{l}\text { Elevated } \\
\text { hemidiaphragm due to } \\
\text { postoperative } \\
\text { diaphragmatic } \\
\text { dysfunction; partial/ } \\
\text { complete opacification } \\
\text { of the ipsilateral thorax } \\
\text { depending on the extent } \\
\text { of resection and time } \\
\text { interval postsurgery. } \\
\text { Bronchopleural fistula } \\
\text { formation with persistent } \\
\text { air leak, depending on } \\
\text { the type of surgery }\end{array}$ & Diagnosis of exclusion & $\begin{array}{l}\text { Supportive; antibiotics, } \\
\text { ventilatory support, } \\
\text { oxygen, vasopressor } \\
\text { support }\end{array}$ \\
\hline
\end{tabular}

ESR erythrocyte sedimentation rate, $C R P$ C-reactive protein, $S D$ standard deviation

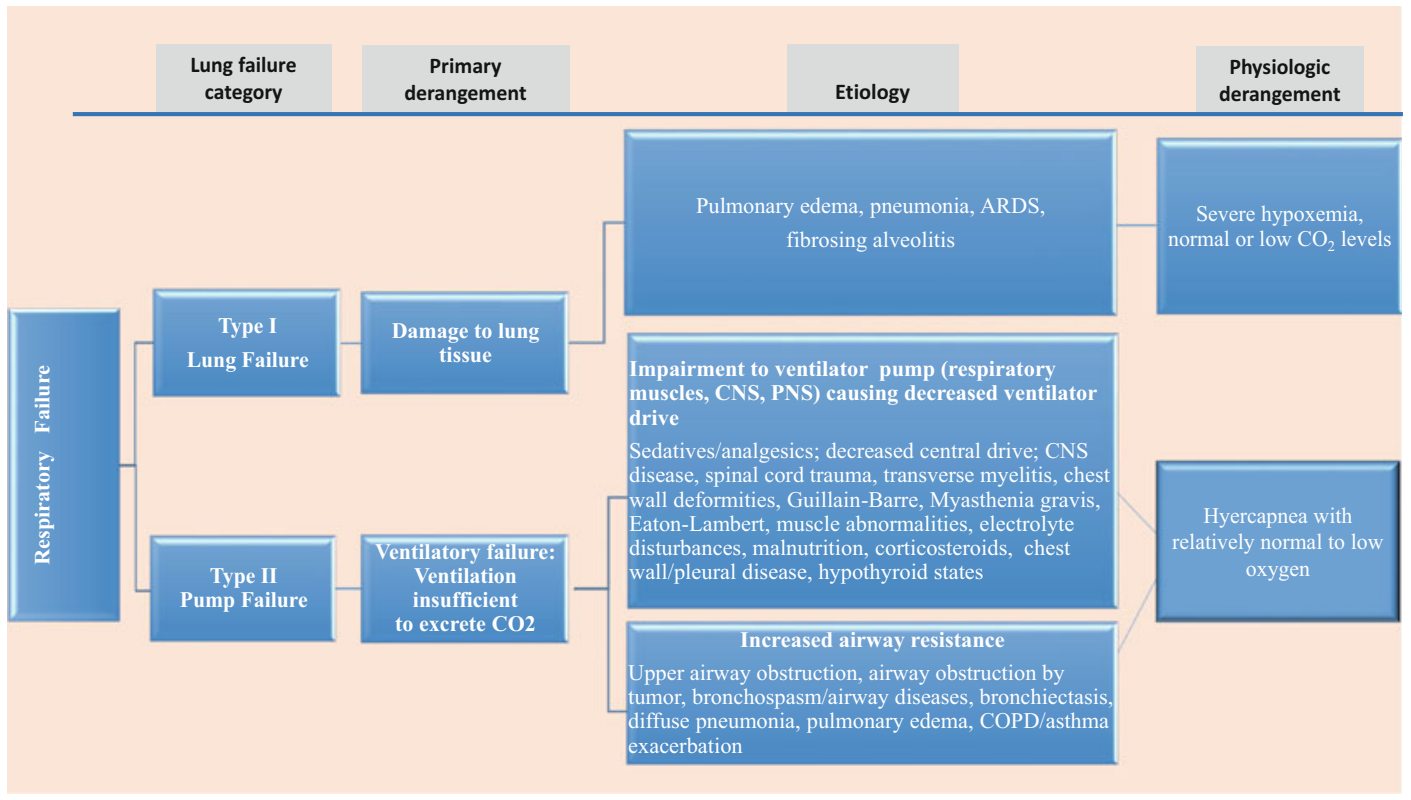

Fig. 1 Lung versus pump failure

common causes of respiratory compromise in patients with cancer. Peripheral muscle impairment owing to electrolyte disturbances, malnutrition, systemic corticosteroids, Eaton-Lambert syndrome, or chest wall disease may also occur. Neurologic and myopathic changes caused by 
chemo- and immunotherapeutic agents such as the taxanes, carboplatin, ipilimumab, and nivolumab are well described [28-31]. Finally, hypothyroidism, brain-stem lesions, and analgesic and sedating medications may cause profound suppression of the central nervous system and pump failure. In the cancer setting, overlapping causes of lung failure and pump failure often coexist, resulting in intractable hypoxemic, hypercarbic respiratory failure.

\section{Primary and Secondary Triggers of ALI/ARDS in the Cancer Patient}

\section{Pneumonia/Opportunistic Infections}

Infections are responsible for approximately $90 \%$ of all primary and secondary causes of ARDS in the cancer setting (Table 3) [32]. Pneumonia is the most common and potentially lethal form of infection in patients with cancer, complicating nearly $10 \%$ of all cancer-related hospital admissions. In patients with hematologic malignancies (HM), rates of pneumonia may exceed $80 \%$ and is a leading cause of death, particularly in the setting of hematopoietic stem cell transplantation (HSCT) and acute leukemias [33]. Studies by Azoulay and others have implicated pneumonia as the underlying trigger for ARDS in $66-80 \%$ of patients with either solid or hematological malignancies. This compares to an incidence of pneumonia-related ARDS of $<60 \%$ among patients without cancer [32, 34, 35]. Opportunistic organisms, including invasive Aspergillus, pneumocystis pneumonia, and candidemia, are prominent causes of primary and secondary ARDS in cancer, accounting for up to $1 / 3$ of cases [36]. Cancer-related and cancer treatmentrelated impairments in immune defense largely contribute to the increased vulnerability of these patients to infections and accounts for the disproportionately high incidence of ARDS in cancer. Cytopenias, treatment toxicities, and other immune derangements are frequent causes of recalcitrant pneumonias, particularly among patients with hematologic malignancies and following HSCT [37-39]. Bacterial pneumonia is the leading cause of ARDS in this setting [33]. Opportunistic fungal diseases, including invasive aspergillosis, Pneumocystis pneumonia, and systemic candidemia, are increasingly common and account for a disproportionate percentage $(31-36 \%)$ of pneumonia-related ARDS in immunocompromised patients compared to the 5-10\% incidence in immunocompetent patients with ARDS [40, 41]. In addition, profound impairments in cell mediated and humoral immunity are risk factors for pneumonias caused by reactivation of latent viral infections, such as cytomegalovirus, varicella zoster virus, and herpes simplex virus. These infections may lead to ARDS as a sequela of primary pneumonia or disseminated disease, particularly among the immune-suppressed HM/HSCT patients and the subgroup of HSCT patients with graft-versus-host disease. Progression of upper respiratory tract infections, including respiratory syncytial virus, influenza, and parainfluenza virus, leading to ARDS may also occur $[42,43]$. Other causes of increased vulnerability to pneumonia in the cancer setting include derangements in lung architecture caused by surgery, radiation or cancer itself, prolonged mechanical ventilation, and swallowing difficulties associated with thoracic tumors, pain, and sedating medications. Finally, repeated exposures to antibiotics and frequent encounters with the healthcare system may promote the development of pneumonias caused by multidrug-resistant pathogens. Once established, these infections may exact an inexorable course, with high associated mortality. Early etiological assessment and initiation of appropriate antimicrobial therapy, along with prompt initiation of critical care, are vital steps in improving outcomes.

In the general patient population, ARDS is thought to complicate $6-7 \%$ of all cases of sepsis [44]. Rates of sepsis causing ALI/ARDS in the cancer setting is thought to be much higher, although the true incidence is unknown. Older age, shock, pneumonia, pancreatitis, Acute Physiology and Chronic Health Evaluation II (APACHE II) scores, and volume of fluid resuscitation over the first $6 \mathrm{~h}$ of presentation are significant risk factors for among septic patients with ARDS [45]. Rates of sepsis and septic shock caused by Gram-negative organisms, as well as other bacterial, fungal, and viral pneumonias, vary 
Table 3 Infectious causes of ARDS

\begin{tabular}{|c|c|c|c|}
\hline Bacteria & Fungi & Viruses & Parasites \\
\hline \multicolumn{4}{|l|}{ Gram-positive bacteria } \\
\hline Staphylococcus aureus & Aspergillus & Adenovirus & Giardia lamblia \\
\hline Streptococcus pneumoniae & Pneumocystis jirovecii & Rhinovirus & Babesia spp. \\
\hline Streptococcus pyogenes & Candida spp. & RSV & Plasmodium spp. \\
\hline Nocardia spp. & Rhizopus spp. & Influenza A, B & Strongyloides stercoralis \\
\hline Rhodococcus equi & P. boydii & Parainfluenza & Toxoplasma gondii \\
\hline Gram-negative bacteria & & Cytomegalovirus & \\
\hline Escherichia coli & & Herpes simplex virus & \\
\hline Nontypeable Haemophilus influenzae & & Herpes varicella zoster & \\
\hline Enterobacteriaceae & & Coronavirus & \\
\hline Stenotrophomonas maltophilia & & Metapneumovirus & \\
\hline Serratia marcescens & & Echoviruses & \\
\hline \multicolumn{4}{|l|}{ Klebsiella pneumoniae } \\
\hline \multicolumn{4}{|l|}{ Nocardia spp. } \\
\hline \multicolumn{4}{|l|}{ Acinetobacter baumannii complex } \\
\hline \multicolumn{4}{|l|}{ Alcaligenes/Achromobacter spp. } \\
\hline \multicolumn{4}{|l|}{ Neisseria meningitidis } \\
\hline \multicolumn{4}{|l|}{ Proteus spp. } \\
\hline \multicolumn{4}{|l|}{ Pseudomonas spp. } \\
\hline \multicolumn{4}{|l|}{ Chlamydia pneumoniae enterovirus } \\
\hline \multicolumn{4}{|l|}{ Moraxella catarrhalis } \\
\hline \multicolumn{4}{|l|}{ Burkholderia spp. } \\
\hline \multicolumn{4}{|l|}{ Citrobacter spp. } \\
\hline \multicolumn{4}{|l|}{ Enterobacter cloacae } \\
\hline \multicolumn{4}{|l|}{ Listeria $\mathrm{sp.}$} \\
\hline \multicolumn{4}{|l|}{ Atypical bacteria } \\
\hline \multicolumn{4}{|l|}{ Legionella spp. } \\
\hline \multicolumn{4}{|l|}{ Mycoplasma pneumoniae } \\
\hline \multicolumn{4}{|l|}{ Chlamydophila pneumoniae } \\
\hline Mycobacteria spp. & & & \\
\hline
\end{tabular}

broadly in the cancer setting and roughly correlate with the degree of immune suppression.

\section{Drug-Induced Acute Lung Injury (ALI)/ARDS}

Estimates regarding the incidence of ARDS attributed to chemotherapy agents are imprecise, as the results depend heavily on individual case reports and competing diagnoses, such as infection, may occur concomitantly with drug-induced ARDS. In addition, many antineoplastic agents are prescribed as components of complex multidrug and multimodality regimens, which renders identification of individual drugs as specific culprits difficult. Although nonspecific pneumonitis and organizing pneumonia are the most frequent histopathologic findings in drug-induced lung injury, acute lung injury with DAD/ARDS has been reported in a small percentage of patients across the spectrum of antineoplastic therapies, including the conventional cytotoxic therapies, molecular targeted therapies, and the immunemodulating agents [46-50]. High supplemental oxygen, given concurrently or sequentially, and concurrent granulocyte-colony-stimulating factor or granulocyte macrophage-colony-stimulating factor (G-CSF, GM-CSF) may potentiate chemotherapy-related ARDS [51, 52]. Hyperoxia 
and increased ARDS risk has been most frequently reported in bleomycin-exposed patients $[51,53]$.

\section{Postoperative ARDS}

ALI/ARDS is a leading cause of postoperative respiratory failure, with mortality rates approaching $40 \%$ in the general population. Mortality rates in the cancer population vary broadly (6-76\%), depending on the type of cancer surgery. Thoracic surgeries, in particular intrapericardial or extrapleural pneumonectomy and esophagectomy, confer the highest operative risk for lung injury (Fig. 2). Postoperative acute lung injury in these settings is most often due to pneumonia, pulmonary edema, atelectasis, persistent air leak, bronchopleural fistula, and prolonged mechanical dependence. Nosocomial pneumonias with related acute respiratory failure complicate approximately $20 \%$ of thoracic and upper abdominal cancer surgeries with an associated $50 \%$ mortality rate $[54,55]$. Contributions to postoperative ARDS in cancer are similar to the general population and include aspiration pneumonitis, massive transfusion, shock (septic, hemorrhagic, or anaphylactic), and excessive perioperative fluids. Thoracic surgical resections that involve pneumonectomy, extended surgical manipulation, and single lung ventilation with inherent hyperoxia and volutrauma also confer an increased risk of postoperative ARDS [56]. Few data exist regarding the prevalence of lung injury following lung resection. Most recent series suggest that around 5\% of patients develop some degree of lung injury. Those that develop frank ARDS have a poor prognosis compared to those who suffer lesser degrees of damage. The pathogenesis of ALI/ARDS following intrathoracic resection remains unknown. Perioperative fluid overload, increased blood flow through the remaining lung postoperatively, reoxygenation injury, and activation of
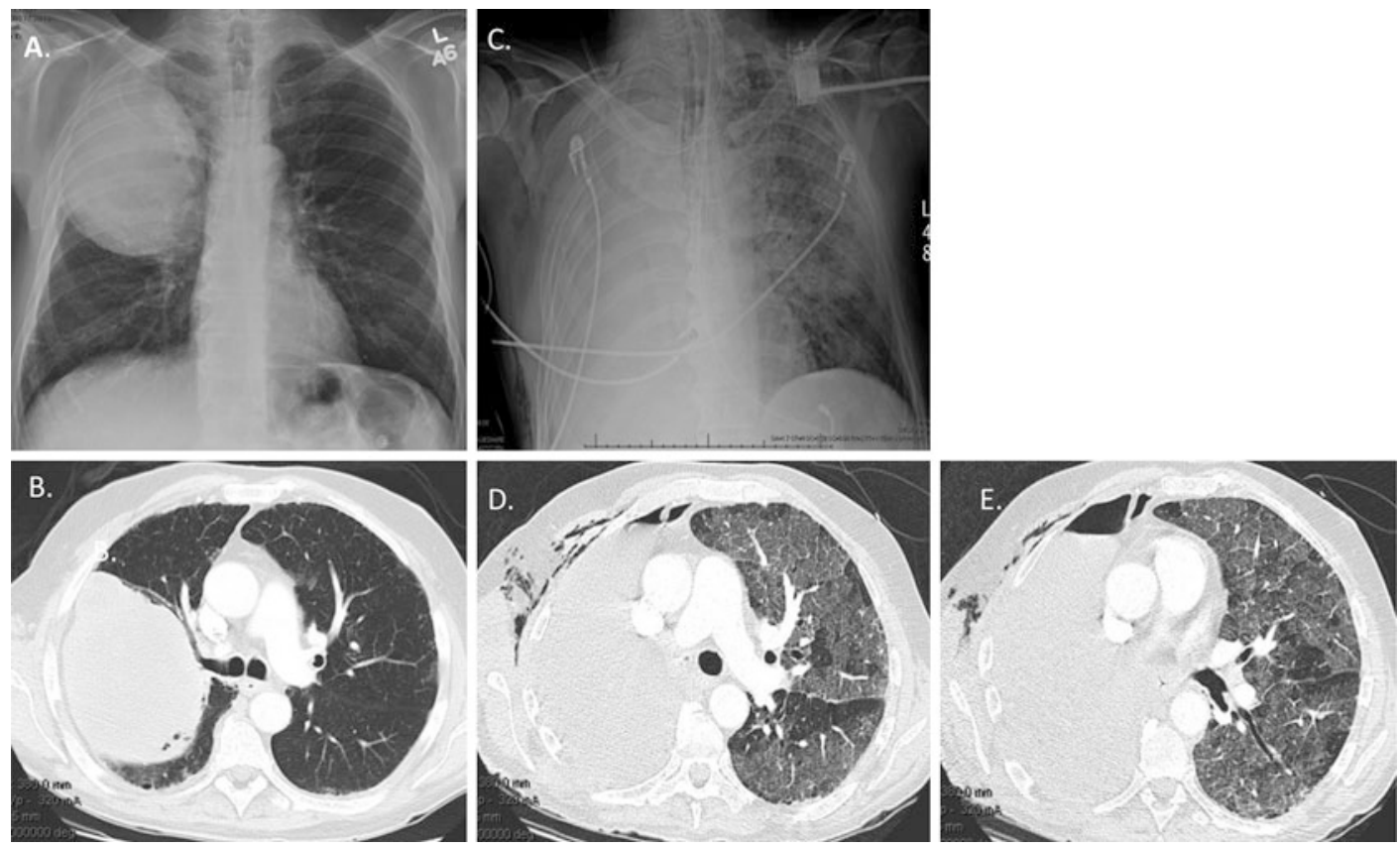

Fig. 2 A 48-year-old man developed severe hypoxemia $48 \mathrm{~h}$ after right pneumonectomy with chest wall resection for primary bronchogenic carcinoma. A large right upper lobe mass abutting the chest wall is seen on baseline chest radiograph and CT $(\mathbf{a}, \mathbf{b})$. Two days later, diffuse groundglass opacities are noted throughout the left lung (c-e).

Postoperative changes related to right pneumonectomy and partial right lateral chest wall resection, including a large amount of subcutaneous emphysema, are also seen. A large amount of subcutaneous emphysema is noted on the right. The patient remained ventilator dependent and succumbed to progressive respiratory failure 
inflammatory mediators have been postulated as possible causes. Conventional parameters for preoperative assessment do not predict those patients most predisposed to develop lung injury following lung resection. Hypoxia and diffuse interstitial pulmonary edema may occur as early as $24-72 \mathrm{~h}$ following pneumonectomy or lobectomy and quickly progress to respiratory failure. Rales on lung examination may become clinically apparent within hours of presentation. Mimickers of ARDS, including pneumonia, pulmonary embolism, cardiogenic pulmonary edema, pulmonary embolism, and bronchopleural fistula formation, should be excluded. Positive pressure ventilation, supplemental oxygen, fluid restriction, and diuretics represent standard of care in this setting, although postpneumonectomy/lobectomy ARDS is inherently refractory to treatment, and $50 \%$ of patients will succumb to their illness [54] (Fig. 3).

The increased risk of ARDS following cardiothoracic surgeries has traditionally been associated with the use of cardiopulmonary bypass (CPB), the need for blood product transfusions, large volume shifts, mechanical ventilation, and direct surgical insult. The impact of ARDS in the cardiac population is substantial, affecting not only survival but also in-hospital length of stay and long-term physical and psychological morbidity. Early identification of high ARDS risk groups are crucial in improving postsurgical outcomes.

\section{ALI/ARDS Post Hematopoietic Stem Cell Transplant}

Lung injury following hematopoietic stem cell transplantation (HSCT) occurs in 30-60\% HSCT recipients, with progression to ARDS in approximately 5\% [57]. Risk factors for ARDS in this setting include pneumonia, shock, sepsis, and aspiration. ARDS is more frequent $(61 \%$ versus $3 \%$ ), more severe, and occurs at a later time point (median 55 days compared 14 days) among recipients of allogeneic transplants versus autologous HSCT. This likely reflects increased vulnerability to infection owing to more intense immune suppression among allogeneic recipients. Not surprisingly, posttransplant outcomes among this group of patients with ARDS are poor, with increased ICU days ( 9 days vs. 6.8 days among autologous recipients) and higher ICU mortality [58].

Transfusion-related acute lung injury (TRALI)/transfusion-related ARDS is a distinct clinical condition, characterized by acute lung injury with hypoxemia $\left(\mathrm{PaO}_{2} / \mathrm{FiO}_{2}<300 \mathrm{~mm}\right.$ $\mathrm{Hg}$ ), fever, hypotension, cyanosis, and bilateral pulmonary infiltrates. The diagnosis of TRALI requires a temporal relationship between transfusion of blood products and the development of acute lung injury and the exclusion of other competing risk factors for ARDS, such as pneumonia, sepsis, pancreatic, drug toxicity, or trauma. A growing consensus supports a "two-hit model" in the development of TRALI, in which an inflammatory condition, such as infection or trauma in the lungs, leads to sequestration and priming of lung neutrophils. With subsequent blood/blood product transfusion, antibodies and endotoxins in stored blood promote endothelial damage by inducing the release of oxidases and proteases from the primed neutrophils. This sequence of events results in capillary leak and acute lung injury $[59,60]$. Although the precise incidence of TRALI in the general population is unknown, historical estimates suggest that TRALI develops in approximately 1 in 5000 transfused blood components, or $0.1 \%$ of transfused patients [61]. TRALI may be more frequent in the cancer setting and the ICU, where susceptible patients are some of the highest consumers of blood and blood product support.

Symptoms of TRALI typically occur early (within minutes of initiation a transfusion) but may be delayed up to $6 \mathrm{~h}$ following blood product administration. Chest imaging studies demonstrate patchy infiltrates unrelated to cardiogenic pulmonary edema. Virtually all blood products, including fresh frozen plasma, packed red blood cells (PRBCs), platelets, granulocytes, cryoprecipitate, intravenous immune globulin, and allogeneic stem cells, have all been implicated in the development of this syndrome [60, 62, 63]. Specific risk factors for TRALI may be stratified according to recipient factors and blood 


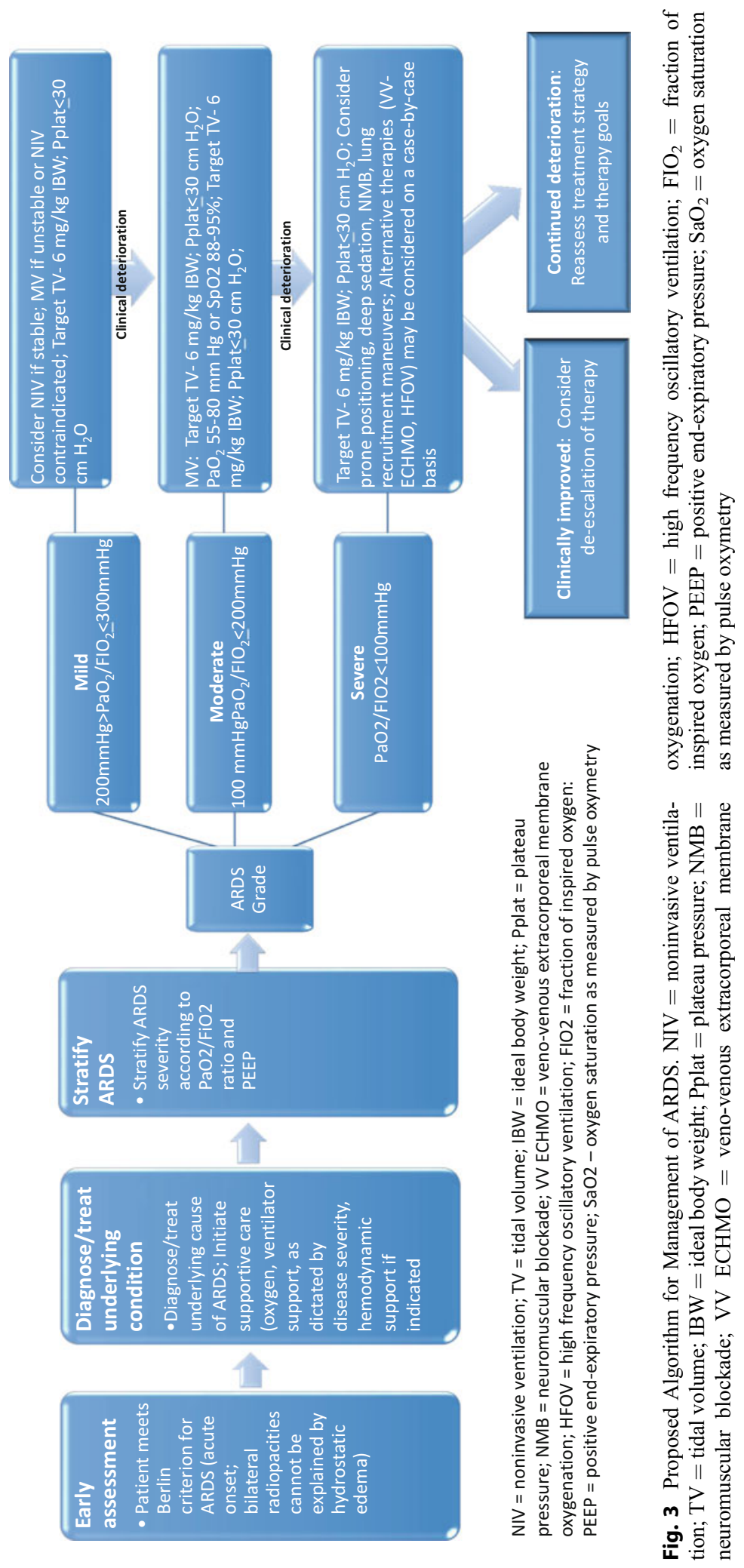


product factors. Recipient factors include hematologic malignancy, critical illness, emergency cardiac surgery, massive transfusion, sepsis, mechanical ventilation, and a high APACHE II scores [64]. General surgery, cytokine infusion, and active infection have also been linked to TRALI, although these associations have not been confirmed. Blood product factors have included transfusions of whole blood and donor gender, with increased rates associated with increased plasma or whole blood from female donors [65-67]. Numerous studies have explored the influence of RBS storage time on transfusionrelated adverse events, including TRALI and posttransfusion infections, with mixed results [68-70]. More recent studies suggest that transfusion of fresh (1-10 days old) RBCs does not confer superior transfusion outcomes to the standard practice of transfusing blood stored for up to 3 weeks [71]. Supportive measures, including initiation of supplemental oxygen and hemodynamic support, are the cornerstones of TRALI therapy. Noninvasive respiratory support with continuous positive airway pressure (CPAP) is indicated in patients with mild disease. However, approximately $70-80 \%$ of patients will require invasive mechanical ventilation [61, 72, 73]. High-dose intravenous steroids have been reported to have success in individual case reports, although no prospective trials exist and existing anecdotal evidence favoring the use of steroids in the management of TRALI is limited [74]. Upon suspicion of TRALI, the transfusion should be immediately discontinued and the blood bank alerted of a possible transfusion reaction. With the recognition that alloimmunization during pregnancy renders multiparous women as high-risk donors in the development of TRALI, national and international risk-reduction strategies have been implemented over the past decade that exclude multiparous women as donors with the preferential utilization of males and nulligravida donors in whole blood and high plasma volume components transfusions [75-78]. These mitigation strategies do not currently apply to platelet or red blood cell products, due to concerns that broader applications may result in donor shortages of platelets and red blood cell products. Other risk-reduction strategies, including use of solvent-detergenttreated plasma, and more stringent screening of blood and blood product donors have also been implemented. These efforts have resulted in a significant reduction in both TRALI-related incidence and mortality rates. The prognosis is substantially more favorable compared to other causes of acute lung injury, with many survivors exhibiting full recovery [74].

\section{ALI/ARDS Due to Pulmonary Spread of Tumor: Lymphangitic Carcinomatosis and Pulmonary Leukostasis}

Tumoral involvement of the pulmonary vascular bed may present as occlusion of small airways by tumor microemboli or macrovascular occlusion of central pulmonary vessels caused by large tumor emboli. Choriocarcinomas and tumors of mucinous origin from the breast, lung, gastrointestinal tract, and kidneys are associated with the highest rates of tumor embolization. Lymphangitic spread of tumor frequently accompanies tumor microembolization. However, either entity may exist in isolation. Hyperleukocytosis, variably defined as a WBC greater than $50 \times 10^{9} / \mathrm{L}(50,000 /$ microL) or $100 \times 10^{9} / \mathrm{L}(100,000 /$ microL $)$ with leukostasis, may result in leukemic sequestration and leukocyte thrombus formation within the pulmonary microvasculature. This disorder is most often seen among patients with acute or chronic myeloid leukemias in blast crisis and is considered an oncologic emergency. The markedly elevated and poorly deformable blast cells are thought to plug the microcirculation, leading increased blood viscosity, leukostasis, and tissue hypoperfusion. Cytokine production by the dividing blast compound the problem by damaging the endothelial lining cells, resulting in alveolar hemorrhage [79, 80]. Patients with microvascular thrombosis typically present with an insidious dry cough, progressive dyspnea, and hypoxemia in association with echocardiographic evidence of pulmonary hypertension and cor pulmonale. Interstitial infiltrates suggestive of lymphangitic spread of disease may also be seen. The prognosis 
is conditioned by the type of malignancy (patients with acute myeloid leukemias in blast crisis tend to do worse) and evidence of end-organ damage (renal, neurologic, respiratory) [81]. Treatment of leukostasis with hyperleukocytosis includes stabilization with urgent efforts to reduce the WBC count with cytoreduction, hydroxyurea, and/or leukapheresis. Avoidance of whole blood transfusions may also help to mitigate blood hyperviscosity and symptomatic hyerleukostasis. Intravenous hydration, correction of coagulation abnormalities including disseminated intravascular coagulopathy, and aggressive platelet support are the mainstays of treatment.

Initiation of chemotherapy for treatment of acute nonlymphocytic leukemia has been reported to precipitate acute hypoxemic respiratory failure and is thought to be caused by chemotherapyinduced pulmonary leukostasis and perivascular hemorrhage. This syndrome, known as leukemic cell lysis pneumopathy, has been reported following chemotherapy for acute myelomonocytic leukemia. Patients typically present within the initial $48 \mathrm{~h}$ of treatment for leukemia with severe hypoxemia associated with new or worsening pulmonary infiltration on chest radiography. Lysis of leukemic cells, with subsequent release of their enzyme contents, leading to diffuse alveolar damage and ARDS is the postulated mechanism of lung injury [82]. Measured $\mathrm{PaO} 2$ may be artificially low in patients with hyperleukocytic leukemias in the absence of lung involvement, owing to leukocyte metabolism of oxygen within the arterial blood gas syringe. In this setting oxygen saturations obtained by pulse oximetry are normal. Rapid analysis of the arterial blood gas specimen kept on ice or the addition of cyanide to the blood gas syringe effectively eliminates this problem.

Patients with macrovascular tumor emboli may present with acute onset dyspnea and hypoxemia with pleuritic chest pain. Symptoms and signs closely resemble acute pulmonary thromboembolic disease, and premortem distinctions between the two entities are often difficult to discern. Microvascular tumor embolization, however, typically presents with insidious symptoms of dyspnea, nonproductive cough, hypoxemia, and severe pulmonary artery pressure elevations.
Cor pulmonale and diffuse interstitial infiltrates, suggestive of lymphangitic spread of disease, are common findings and heighten the already poor prognosis.

\section{Clinical Presentation and Diagnostic Workup of ALI/ARDS}

The clinical, histopathologic, and radiographic manifestations of ALI/ARDS are highly varied. Acute respiratory failure with refractory hypoxemia is typical during the exudative stage of ALI/ARDS. Patients commonly develop clinical manifestations of lung injury early, usually within $24 \mathrm{~h}$ of exposure to the injurious agent. Progression to respiratory failure and the need for noninvasive and/or invasive ventilation also occurs early (within the first $72 \mathrm{~h}$ of onset) in $90 \%$ of patients $[34,83]$. Imaging findings vary with the severity of ARDS. Bilateral areas of patchy airspace consolidation within the lung periphery with normal cardiac silhouette and absence of Kerley B lines are classic findings on chest radiographs. On computed tomography (CT), alveolar filling and consolidation within dependent areas of the lungs are also characteristic. These findings may appear as subtle ground-glass opacities during early stages of ALI/ARDS but evolve to dense consolidative changes as the disease progresses. Imaging abnormalities may closely mimic cardiogenic edema, which should be excluded. Clinical manifestations, including progressive dyspnea, tachypnea, tachycardia, cough, and diffuse rales, are notoriously nonspecific findings. With disease progression, respiratory distress, cyanosis, altered mental status, and chest pain (owing to pneumothorax in some cases) may occur. Acute hypoxemia and a compensatory respiratory alkalosis are common early derangements on arterial blood gases. The development of hypercapnic respiratory acidosis signals severe disease with impending respiratory failure and portends a poor prognosis.

The goal of the diagnostic evaluation of ARDS is to identify the underlying cause(s) and provide guidance for immediate empirical treatment. Early identification and treatment of the cause(s) 
of ARDS has been shown to favorably impact outcomes [36, 84-89]. Thus, the evaluation and relevant testing should be performed as early as possible, starting with a thorough history and clinical examination and chest imaging. Chest radiographs and $\mathrm{CT}$ imaging may provide critical clues to the diagnosis and help to exclude competing entities, such as pneumonia (lobar consolidation, air bronchograms, cavitation) and cardiogenic pulmonary edema (presence of Kerley B lines, cardiomegaly, pulmonary venous congestion, pleural effusions). Diagnostic yields of bronchoscopically obtained lavage (BAL) fluid in the cancer setting vary widely $(30-89 \%)$ but may be helpful in evaluating infectious etiologies $[28,90]$. Common underlying infectious triggers for ARDS in the cancer setting may be identified on BAL fluid, including bacteria, invasive mycotic infections, tuberculosis, pneumocystis, and viral pathogens. In addition, elevated eosinophils, bloody fluid with increased hemosiderinladen macrophages, and malignant cells on BAL fluid are helpful clues in the diagnosis of acute eosinophilic pneumonia conditions, diffuse alveolar hemorrhage, or lymphangitis carcinomatosis, respectively. The utility of lung biopsies in this setting has been debated. The underlying trigger (s) for ARDS are typically identified using less invasive strategies, and the likelihood of obtaining additional information has to be carefully weighed against the overall risk of the surgical procedure. Nonetheless, surgical biopsies may be reasonable when a specific pathology and/or reversible etiology (such as lymphangitic spread of disease, vasculitis, or cryptogenic organizing pneumonia) is suspected but not obvious from less invasive studies or when surgically obtained biopsies may inform critical therapeutic and prognostic decision-making.

Complete blood count (CBC), coagulation studies, chemistries, liver function tests, and arterial blood gas (ABG) analysis should be included in the initial blood work. Brain natriuretic peptide (BNP) or pro-N terminal BNP (pro-NT BNP) and troponin levels may help to exclude cardiogenic causes of pulmonary edema. Serum lipase and amylase levels to evaluate for pancreatitis should be investigated in patients with abdominal symptoms and no other obvious triggers for ARDS. Laboratory evidence of organ injury associated with hypoxemia (transaminitis, acute renal insufficiency) are frequent findings with advanced disease. Metabolic acidosis may reflect major organ sites of involvement (liver, kidneys) or sepsis. Depending on the clinical suspicion, other components of the ARDS evaluation may include nasopharyngeal aspiration for respiratory viral panel, urinary antigens and cultures for legionella or Streptococcus pneumoniae, and PCR for Pneumocystis jirovecii and herpes simplex virus. Depending on the underlying trigger, the white cell count may be elevated, depressed, or normal. ARDS should be considered in any patient who develops progressive dyspnea, hypoxia, and bilateral pulmonary infiltrates on chest imaging within $6 \mathrm{~h}$ to 1 week of an inciting event. Unfortunately, the inciting event is frequently unknown, and early signs and symptoms are often missed. Recovery or death may occur at any stage of ARDS. Prognosis is primarily dependent on the severity, chronicity, and treatment of ARDS rather than the etiology of lung injury. Survivorship among those patients that progress to the fibrotic phase of ARDS is marked by long-term oxygen dependence and a decreased quality of life.

\section{Cancer-Related ALI/ARDS: Outcomes and Treatment}

Conditions common to ARDS, such as infection, respiratory failure, hemodynamic instability, disseminated intravascular coagulation, sepsis, and gastrointestinal (GI) bleed, are independent predictive variables that presage poor outcomes. Assessments of illness severity at the time of ICU admission, using SOFA (sequential organ failure assessment) scores, are also helpful in identifying the high-risk patients with predicted poor outcomes [91]. Although the treatment of ARDS in patients with cancer is similar to that in the non-cancer setting, unique manifestations of cancer and its treatment, including increased rates of neutropenia, infection, thrombocytopenia, mucositis, and thrombosis, represent decisive challenges that highlight the added complexity 
Table 4 Prognosis of ARDS in cancer

\begin{tabular}{l|l|l|l|l|l}
\hline Type of malignancy & \# Patients & \multicolumn{2}{l|}{ Mortality (\%) } & Reference \\
\hline Leukemia patients post HSCT & & 28 day & In-hospital & 6 months & \\
\hline Hematologic & 2635 & & & $66.90 \%$ & Yadav et al. [58] \\
\hline Hematologic & 68 & $77 \%$ & & & Türkoğlu [134] \\
\hline Mixed solid/hematologic & 70 & $63 \%$ & & & Mokart (2012) \\
\hline Mixed solid/hematologic & 116 & $55.20 \%$ & & & Soubani et al. [25] \\
\hline $\begin{array}{l}\text { Hematologic } \\
\text { Mixed cancers (13\%), all others no cancer } \\
\text { history }\end{array}$ & 3022 & $34 \%$ & 39.6 & & Azoulay et al. [32] \\
\hline
\end{tabular}

of managing ARDS in cancer patients. Mortality rates in excess of $90 \%$ have been reported among cancer patients requiring mechanical ventilation for ARDS in the past, with the highest vulnerability among patients with hematologic malignancies and recipients of hematopoietic transplants $[92,93]$. Recent investigations suggest significant declines in mortality rates (30-63\%) and offer a more favorable perspective $[25,85,90]$ Table 4 . These survival gains have been attributed to early identification and management of precipitating condition(s) coupled with improvements in prophylaxis measures for infection and aspiration over the past decade [94]. In addition, improved HSCT techniques, including more aggressive use of hematopoietic growth factor support and the increasing use of donor stem cells from a peripheral rather than bone marrow source, have also had salutary effects on ARDS mortality. Convincing evidence has also shown earlier ICU transfer within $48 \mathrm{~h}$ of onset of respiratory symptoms is also associated with improved survival [85, 95]. Finally, the expanded use of NIV and lung protective strategies that attenuate ventilatorassociated lung injury have been central to improved ventilator outcomes [90, 94, 96].

Pulmonary function usually may return to normal within 6-12 months following mild to moderate ARDS. Patients with severe disease and those requiring prolonged ventilatory support may develop persistent abnormalities in pulmonary function, disabling muscle weakness and neuropsychiatric deficiencies. Studies have shown the beneficial impact of daily interruption of sedation and spontaneous breathing trials (wake up and breathe protocol) and of early mobilization of mechanically ventilated patients, as part of a comprehensive multifaceted strategy to curtail long-term complications from ARDS.

\section{Treatment}

\section{Pharmacologic Therapies}

Despite extensive investigations, evidence supporting the utility of most pharmacologic therapies in adult ARDS management are limited. Randomized controlled trials and cohort studies suggest that high-dose glucocorticoids may offer some mortality benefit, particularly if given early, during the fibroproliferative phase of ARDS; however a consistent mortality advantage has not been shown [97-99]. Furthermore, an optimal steroid dose (range $1 \mathrm{mg} / \mathrm{kg} /$ day to $120 \mathrm{mg} / \mathrm{kg} /$ day in various studies) has not been established. Exogenous surfactant therapy may be beneficial in the management of childhood ARDS, but has not been found to be of therapeutic utility in adults. Results of other pharmacologic investigations including anti-TNF- $\alpha$, anti-interleukin-1, ketoconazole, prostaglandin E1, prostacyclin, and inhaled nitric oxide in attenuating ARDS risk and/or improving ARDS outcomes have been equally disappointing $[100,101]$.

Respiratory and hemodynamic support along with diuretics, vasopressors, and antibiotics, where indicated, are standard supportive care measures in ALI/ARDS. Intravenous fluids should be given judiciously, with careful attention 
to fluid homeostasis, as persistent positive fluid balance has been associated with increased days on the ventilator and poor clinical outcomes [102, 103]. Thus, conservative intravenous fluid hydration titrated to lower central pressures is recommended [104, 105]. Unless contraindicated prophylaxis against venous thromboembolism using low-molecular-weight heparin (40 mg of enoxaparin) or 5000 units of subcutaneous dalteparin per day) or low-dose, unfractionated subcutaneous heparin (5000 units twice daily) is recommended. Nonpharmacologic measures to reduce thrombus risk, such as intermittent pneumatic compression (IPC), should be considered when anticoagulant therapy is contraindicated. IPC therapy has proven benefit in reducing DVT in the postoperative setting, although rigorous investigations of this device as a stand-alone intervention in the nonsurgical setting are not available. Patients should also receive daily stress ulcer prophylaxis with sucralfate, ranitidine, or omeprazole, unless contraindicated. Nutritional support should be initiated within $24-48 \mathrm{~h}$ of ICU transfer and preferably by enteral route, in accordance with ADA guidelines [106]. Successful management of ARDS also requires an expeditious evaluation and treatment of nosocomial and community-acquired pneumonias and other secondary infections. Meticulous glycemic control, prevention of aspiration events, and careful management of gastrointestinal (GI) bleeding are also frequent issues among cancer patients with ARDS that mandate careful monitoring and coordination with other therapies.

\section{Noninvasive and Invasive Ventilation}

Noninvasive ventilation (NIV) has gained broad acceptance in the management of cancer patients with respiratory failure, based on pivotal randomized, controlled studies that have demonstrated unequivocal efficacy of NIV in the management of patients with pump failure $[107,108]$ as well as selected cases of lung failure [107]. In a recent retrospective study of the outcome of cancer patients following ICU transfer for ARF, the use of NIV was associated with marked improvements in patient survival [90]. In addition, significant reductions in both ICU and post ICU hospital mortality have been linked to the use of intermittent NIV during the early stages of hypoxemic ARF $\left(\mathrm{PaO}_{2} / \mathrm{FiO}_{2}\right.$ ratio <250) [84, $108,109]$. The use of NIV has also been associated with significant declines in the need for conventional mechanical ventilation. However, these favorable results may apply only to a subset of patients in the early stages of ARDS and should be interpreted with caution. The application of NIV in the LUNG-SAFE study was associated with worse mortality [109]. Very few investigations have demonstrated improved survival among cancer patients with ARDS treated with NIV. In one small randomized controlled study of immunocompromised patients with hypoxemic acute lung injury, initiation of NIV resulted improved oxygenation and a reduced need for endotracheal intubation. However, intubation was associated with mortality rates of up to $94 \%$ in the control group, suggesting that survival gains in cancer patients with ARDS may be overestimated. Other studies have demonstrated equally high mortality rates among cancer patients who failed NIV and subsequently required mechanical ventilation. NIV may be sufficient in cancer patients with mild or incipient ARDS, with mechanical ventilation reserved for patients with more advanced disease. Increasing NIV duration, steroid therapy, other organ failure (including renal failure), the need for vasopressor support, and lack of definite etiological triggers for ARDS are reported predictors of NIV failure in the cancer setting. Knowledge of determinants of increased risk for NIV failure may help to better triage patients for NIV versus early intubation and mechanical ventilation as first-line ventilator support. Patients treated with NIV should undergo close surveillance for early signs of NIV failure. Persistent hypoxemia, advanced ARDS, end-organ dysfunction, and altered mental status signal a poor NIV outcome and the need for intubation and mechanical ventilation [87, 109, 110].

Mechanical ventilation, the cornerstone of ARDS treatment, poses a critical conundrum. This intervention is potentially lifesaving and, at the same time, potentially deadly [5]. The ability 
of this therapeutic intervention to potentiate lung injury and contribute to nonpulmonary organ failure is well established [96, 111]. Increased respiratory drive and excessive pulmonary dead space are key features of ARDS. As ARDS progresses, these physiologic derangements drive minute ventilation to unsustainable levels, resulting in progressive hypercapnia. The goals of mechanical ventilation - to improve oxygenation and eliminate $\mathrm{CO}_{2}$ - are met through adjustments in tidal volumes, driving pressures, gas flows, and respiratory rates. Excessive adjustments in these parameters may result in ventilator-induced lung injury (VILI). VILI is manifested clinically as volutrauma (excessive generalized mechanical stress and strain on the lung) and atelectrauma (injury caused by shearing forces as adjacent alveoli collapse and re-expand during mechanical ventilation). VILI tends to be heterogeneous, with injured or atelectatic areas adjacent to relatively normal aerated areas.

Ventilator strategies in the past utilized large tidal volumes $(10-15 \mathrm{mg} / \mathrm{kg})$ and high PEEP (12 cm H2O or greater) in an effort to recruit and maintain open small airways. Lung recruitment maneuvers, which entail the application of high airway pressures and or PEEP for variable duration of time, were also used in an attempt to open collapsed lung units. The salutary effects of increased PEEP in improving oxygenation and mitigating atelectrauma are often offset by the attendant damaging consequences of high alveolar pressures and volumes. The adverse effects of these high pressure strategies are further aggravated by the inhomogeneity of lung damage in ARDS, causing some alveolar units to be under more mechanical stress than others. Convincing evidence from aggregate studies has demonstrated increased volutrauma and 28-day mortality among patients with severe ARDS when these strategies were applied [112].

The intent of mechanical ventilation, to rest the respiratory muscles and maintain adequate gas exchange while the underlying cause of lung injury is being treated, must be balanced by efforts to mitigate the deleterious effects of VILI. Efforts to achieve these goals have been the subject of many clinical trials. More recent approaches advocate lowering airway pressures, which offers the dual benefit of minimizing over distension of the aerated areas and mitigating trauma from repeated opening and closing of the alveoli. The American Thoracic Society (ATS), the European Society of Intensive Care Medicine (ESICM), and the Society of Critical Care Medicine (SCCM) met in 2013-2014 to analyze evidence regarding the use of ventilatory strategies established by the ARDSNET trial. Key recommendations that emerged from these meetings included lowering of targets for tidal volumes $(4-8 \mathrm{ml} / \mathrm{kg}$ predicted body weight) and inspiratory pressures to maintain plateau pressures of $<30 \mathrm{~mm} \mathrm{H} 20$. Low tidal volume strategies have been associated with a $22 \%$ relative reduction in mortality when tidal volumes are maintained at $6 \mathrm{~mL} / \mathrm{kg}$ PBW compared with $12 \mathrm{~mL} / \mathrm{kg}$ [96]. However, this strategy is limited by subsequent hypercapnia and respiratory acidosis as ARDS progresses. In addition, attendant low lung volumes and atelectasis contribute to increased pulmonary vascular resistance. The utility of an extracorporeal carbon dioxide gas exchanger device or the veno-venous extracorporeal membrane oxygenation (VV ECMO) for removal of carbon dioxide has been studied with promising results, although this strategy remains experimental [113-115]. Investigations probing the utility of ECMO and VV ECMO systematically excluded cancer patients with less than a 5-year life expectancy from many of the larger clinical trials. Thus, even less is known regarding the utility of these invasive mechanical devices in patients with ARDS in the cancer setting.

The ATS, the ESICM, and the SCCM also recommend prone positioning. This approach promotes more uniform distribution of mechanical forces throughout the injured lung, thereby facilitating more homogeneous lung inflation and, as a result, improved oxygenation and reduced VILI. The adoption of prone positioning as adjunctive therapy for ARDS had been stalled for many years, based on early clinical trials that demonstrated improved oxygenation, but no survival gains with this intervention. This observation, coupled with concerns regarding possible adverse events from proning patients, including 
facial edema, of pressure necrosis with skin breakdown, transient desaturation, hemodynamic instability, dislodgement of lines and endotracheal tubes, lead to only sporadic use of this treatment modality over the years. However, findings from a patient meta-analysis of four major clinical studies as well as the PROSEVA trial clearly demonstrate a mortality benefit with prone positioning among a subgroup of patients with severe ARDS [5, 116-123]. Based on these observations, prone positioning for patients with severe ARDS is recommended. This recommendation, which is strongly endorsed by major critical care and thoracic societies, marks a major shift in advised care for ARDS. Prone positioning for a minimum of $12 \mathrm{~h}$ per day is recommended for patients with severe ARDS. $\mathrm{P} / \mathrm{F}$ ratios of 100 are also recommended.

Theoretically, the concept behind high-frequency oscillatory ventilation (HFOV), which uses very small tidal volumes oscillating a very high mean pressure, should improve ARDSrelated mortality as a result of its mitigating effects on both volutrauma and atelectrauma. However, two large clinical trials failed to discern any mortality advantage using this ventilator strategy. In fact, the OSCILLATE trial, which compared ARDS outcomes among patients undergoing early application of HFOV to patients undergoing low tidal volume/high PEEP ventilator strategies, was discontinued prematurely due to safety concerns, including hemodynamic issues and higher 28-day mortality. Thus, studies do not support the use of HFOV in patients with ARDS, except perhaps in the patient with very severe ARDS $(\mathrm{P} / \mathrm{F}$ ratio $<64 \mathrm{mmHg}$ ), although more research is needed [124-128].

The past three decades has witnessed a proliferation of newer modes of assisted mechanical ventilation, including airway pressure release ventilation (APRV), proportional assist ventilation (PAV), mandatory minute ventilation (MMV), neurally adjusted ventilatory assist (NAVA), adaptive support ventilation (ASV), and SmartCare. In the conventional volume/pressure "open loop" ventilator strategies, delivered parameters are fixed and lack ability to integrate patient feedback into adjusted ventilator settings.
The newer "closed-loop" ventilator strategies are designed to adjust ventilator settings based on patient feedback, thereby optimizing patientventilator synchrony, improving patient safety and comfort, and mitigating the work of breathing $[129,130]$. Earlier liberation from the ventilator is also facilitated by closed-loop ventilator strategies. However, long-term studies are needed to prove efficacy and to define their true advantages and benefits compared to conventional ventilation strategies, particularly as they relate to mechanically ventilated patients with ARDS.

\section{Sedation and Neuromuscular Blockade}

Sedation and neuromuscular blockade are important components of strategies aimed at optimization of patient-ventilator interactions and minimizing patient discomfort and agitation while on the ventilator. Neuromuscular-blocking agents (NBA) are indicated when asynchrony persists despite sedation and ventilator adjustments [131]. When prescribed early in the course of ARDS, these agents may reduce VILI by several pathophysiologic mechanisms. Paralytic agents eliminate patient-initiated double triggering, ensuring delivery of low tidal volumes. In addition, atelectrauma is reduced by eliminating active exhalation and loss of PEEP. Finally, the high ventilator demands and hypercapnia-associated escalations in respiratory drive that are intrinsic to severe lung injury are mitigated. These benefits may translate to favorable survivals. At least one study has demonstrated survival gains among NBA-treated patients with severe ARDS (P/F ratio <150) compared to nonparalyzed controls $[132,133]$.

\section{Conclusion}

Over the past two decades, ALI/ARDS definitions have crystallized. ARDS is increasingly recognized as a heterogeneous condition, fueled by a variety of triggers. Specific triggers are now accepted as important contributors to unique ARDS phenotypes as well as prognosis and 
response to treatment. Thus, early and aggressive reversal of the inciting event is as pertinent as specialized treatment options, including ventilator strategies and other supportive measures. Furthermore, recognition of different ARDS phenotypes may assist in developing personalized ventilator strategies that consider each patient's unique physiology, thereby mitigating VILI and improving ARDS outcomes. Recent decades have witnessed pivotal advances in evidence-based ARDS treatment strategies. These advances have resulted in significant overall improvements in ARDS mortality in the general population. Survival gains have been largely attributed to optimized approaches to pneumonia and other underlying causes of ARDS, as well as increased utilization of multimodal treatment strategies that include lung-protective ventilation. ARDS prognosis among ventilated patients in the cancer setting have evolved from dismal to encouraging, although mortality rates remain high. The unique vulnerability of cancer patients to respiratory complications caused by the cancer itself, infections, toxic effects of cancer therapies, immune suppression, and cancer- and treatment-related cytopenias frequently contributes to severe lung injury that results in delays and oftentimes discontinuation of cancer therapy. Moreover, long-term morbidity and decreased quality of life among cancer survivors may be substantial. Because of the propensity for severe manifestations of ARDS at presentation, NIV may not be the best option for many cancer patients with acute lung injury. The prognosis following transition to mechanical ventilation following NIV failure remains bleak. These considerations underscore the urgent need for upfront conversations with the patient and family members, together with the oncologist and ICU team in an effort to design a realistic critical care treatment plan that avoids therapeutic intransigence while simultaneously considering the patient's wishes and life expectancy. Treatment strategies for ARDS in the cancer setting have largely been extrapolated from investigations that focus on ARDS in the general population. Studies that focus on the unique challenges of the cancer patient with ARDS are urgently needed.

\section{References}

1. Ashbaugh D, Bigelow D, Petty T. Acute respiratory distress in adults. Lancet. 1967;2:319-23.

2. Bernard GR, Artigas A, Brigham KL, Carlet J, Falke K, Hudson L, Lamy M, Legall JR, Morris A, Spragg R. The American-European consensus conference on ARDS. Definitions, mechanisms, relevant outcomes, and clinical trial coordination. Am J Respir Crit Care Med. 1994;149:818-24.

3. Ranieri VM, Rubenfeld GD, Thompson BT, Ferguson ND, Caldwell E, Fan E, Camporota L, Slutsky AS. Acute respiratory distress syndrome: the Berlin definition. JAMA. 2012;307:2526-33.

4. Murray J, Mathay M, Luce J, et al. An expanded definition of the adult respiratory distress syndrome. Am Rev Respir Dis. 1988;138:720-3.

5. Fan E, Brodie D, Slutsky AS. Acute respiratory distress syndrome: advances in diagnosis and treatment. JAMA. 2018;319:698-710.

6. Steinberg K, Ruzinski J, Caldwell E, Radella F 2nd, Davis D, Treece P, Hudson L, Martin T. The heterogeneity of BAL cells and protein in patients at risk for and with ARDS. Chest. 1999;116:98S.

7. Martin TR. Lung cytokines and ARDS*: Roger S. Mitchell Lecture 41st Annual Thomas L. Petty Aspen Lung Conference: acute lung injury. Chest. 1999;116:2S-8S.

8. Katzenstein AL, Bloor CM, Leibow AA. Diffuse alveolar damage - the role of oxygen, shock, and related factors. A review. Am J Pathol. 1976;85:209-28.

9. Hamacher J, Lucas R, Lijnen HR, Buschke S, Dunant Y, Wendel A, Grau GE, Suter PM, Ricou B. Tumor necrosis factor-alpha and angiostatin are mediators of endothelial cytotoxicity in bronchoalveolar lavages of patients with acute respiratory distress syndrome. Am J Respir Crit Care Med. 2002;166:651-6.

10. Pittet JF, Mackersie RC, Martin TR, Matthay MA. Biological markers of acute lung injury: prognostic and pathogenetic significance. Am J Respir Crit Care Med. 1997;155:1187-205.

11. Bellingan GJ. The pulmonary physician in critical care * 6: the pathogenesis of ALI/ARDS. Thorax. 2002;57:540-6.

12. Nelson S, Belknap SM, Carlson RW, Dale D, DeBoisblanc B, Farkas S, Fotheringham N, Ho H, Marrie T, Movahhed H, Root R, Wilson J. A randomized controlled trial of filgrastim as an adjunct to antibiotics for treatment of hospitalized patients with community-acquired pneumonia. CAP study group. J Infect Dis. 1998;178:1075-80.

13. Katz JN, Kolappa KP, Becker RC. Beyond thrombosis: the versatile platelet in critical illness. Chest. 2011;139:658-68.

14. Kor DJ, Carter RE, Park PK, Festic E, BannerGoodspeed VM, Hinds R, Talmor D, Gajic O, Ware LB, Gong MN. Effect of aspirin on development of 
ARDS in at-risk patients presenting to the emergency department: the LIPS-A randomized clinical trial. JAMA. 2016;315:2406-14.

15. Abdulnour RE, Gunderson T, Barkas I, Timmons JY, Barnig C, Gong M, Kor DJ, Gajic O, Talmor D, Carter RE, Levy BD. Early intravascular events are associated with development of acute respiratory distress syndrome. A substudy of the LIPS-A clinical trial. Am J Respir Crit Care Med. 2018;197:1575-85.

16. Abdulnour RE, Howrylak JA, Tavares AH, Douda DN, Henkels KM, Miller TE, Fredenburgh LE, Baron RM, Gomez-Cambronero J, Levy BD. Phospholipase $\mathrm{D}$ isoforms differentially regulate leukocyte responses to acute lung injury. J Leukoc Biol. 2018;103:919-32.

17. Reilly JP, Christie JD. Linking genetics to ARDS pathogenesis: the role of the platelet. Chest. 2015;147:585-6.

18. Zhai R, Gong MN, Zhou W, Thompson TB, Kraft P, $\mathrm{Su}$ L, Christiani DC. Genotypes and haplotypes of the VEGF gene are associated with higher mortality and lower VEGF plasma levels in patients with ARDS. Thorax. 2007;62:718-22.

19. Bauer T, Ferrer R, Angrill J, Schultze-Werninghaus G, Torres A. Ventilator-associated pneumonia: incidence, risk factors, and microbiology. Semin Respir Infect. 2000;15:272-9.

20. Dolinay T, Kim YS, Howrylak J, Hunninghake GM, An $\mathrm{CH}$, Fredenburgh L, Massaro AF, Rogers A, Gazourian L, Nakahira K, Haspel JA, Landazury R, Eppanapally S, Christie JD, Meyer NJ, Ware LB, Christiani DC, Ryter SW, Baron RM, Choi AM. Inflammasome-regulated cytokines are critical mediators of acute lung injury. Am J Respir Crit Care Med. 2012;185:1225-34.

21. Makabe H, Kojika M, Takahashi G, Matsumoto N, Shibata S, Suzuki Y, Inoue Y, Endo S. Interleukin-18 levels reflect the long-term prognosis of acute lung injury and acute respiratory distress syndrome. J Anesth. 2012;26:658-63.

22. Meduri GU, Headley S, Kohler G, Stentz F, Tolley E, Umberger R, Leeper K. Persistent elevation of inflammatory cytokines predicts a poor outcome in ARDS. Plasma IL-1 beta and IL-6 levels are consistent and efficient predictors of outcome over time. Chest. 1995; 107:1062-73.

23. Calfee CS, Delucchi KL, Sinha P, Matthay MA, Hackett J, Shankar-Hari M, McDowell C, Laffey JG, O'Kane CM, McAuley DF. Acute respiratory distress syndrome subphenotypes and differential response to simvastatin: secondary analysis of a randomised controlled trial. Lancet Respir Med. 2018;6:691-8.

24. Pepe PE, Potkin RT, Reus DH, Hudson LD, Carrico CJ. Clinical predictors of the adult respiratory distress syndrome. Am J Surg. 1982;144:124-30.

25. Soubani AO, Shehada E, Chen W, Smith D. The outcome of cancer patients with acute respiratory distress syndrome. J Crit Care. 2014;29:183 e187-12.
26. Garcia CS, Pelosi P, Rocco PR. Pulmonary and extrapulmonary acute respiratory distress syndrome: are they different? Rev Bras Ter Intensiva. 2008;20:178-83.

27. Thille AW, Richard JC, Maggiore SM, Ranieri VM, Brochard L. Alveolar recruitment in pulmonary and extrapulmonary acute respiratory distress syndrome: comparison using pressure-volume curve or static compliance. Anesthesiology. 2007;106:212-7.

28. Shannon VR. Pneumotoxicity associated with immune checkpoint inhibitor therapies. Curr Opin Pulm Med. 2017;23:305-16.

29. Dimopoulou I, Bamias A, Lyberopoulos P, Dimopoulos MA. Pulmonary toxicity from novel antineoplastic agents. Ann Oncol. 2006;17:372-9.

30. Matsuno O. Drug-induced interstitial lung disease: mechanisms and best diagnostic approaches. Respir Res. 2012;13:39.

31. Sakai F, Johkoh T, Kusumoto M, Arakawa H, Takahashi M. Drug-induced interstitial lung disease in molecular targeted therapies: high-resolution CT findings. Int J Clin Oncol. 2012;17:542-50.

32. Azoulay E, Lemiale V, Mokart D, Pene F, Kouatchet A, Perez P, Vincent F, Mayaux J, Benoit D, Bruneel F, Meert AP, Nyunga M, Rabbat A, Darmon M. Acute respiratory distress syndrome in patients with malignancies. Intensive Care Med. 2014;40:1106-14.

33. Wong JL, Evans SE. Bacterial pneumonia in patients with cancer: novel risk factors and management. Clin Chest Med. 2017;38:263-77.

34. Bellani G, Laffey JG, Pham T, Fan E, Brochard L, Esteban A, Gattinoni L, van Haren F, Larsson A, McAuley DF, Ranieri M, Rubenfeld G, Thompson BT, Wrigge H, Slutsky AS, Pesenti A. Epidemiology, patterns of care, and mortality for patients with acute respiratory distress syndrome in intensive care units in 50 countries. JAMA. 2016;315:788-800.

35. Cortegiani A, Russotto V, Raineri SM, Gregoretti C, Giarratano A. Dying with or because of invasive fungal infection? The role of immunity exhaustion on patient outcome. Turk J Anaesthesiol Reanim. 2016;44:285-6.

36. Azoulay E, Darmon M. Acute respiratory distress syndrome during neutropenia recovery. Crit Care. 2010;14:114.

37. Leoni D, Encina B, Rello J. Managing the oncologic patient with suspected pneumonia in the intensive care unit. Expert Rev Anti-Infect Ther. 2016;14:943-60.

38. Young AY, Leiva Juarez MM, Evans SE. Fungal pneumonia in patients with hematologic malignancy and hematopoietic stem cell transplantation. Clin Chest Med. 2017;38:479-91.

39. Pergam SA. Fungal pneumonia in patients with hematologic malignancies and hematopoietic cell transplantation. Clin Chest Med. 2017;38:279-94.

40. Taccone FS, Van den Abeele AM, Bulpa P, Misset B, Meersseman W, Cardoso T, Paiva JA, BlascoNavalpotro M, De Laere E, Dimopoulos G, Rello J, 
Vogelaers D, Blot SI. Epidemiology of invasive aspergillosis in critically ill patients: clinical presentation, underlying conditions, and outcomes. Crit Care. 2015;19:7.

41. Eggimann P, Garbino J, Pittet D. Epidemiology of Candida species infections in critically ill non-immunosuppressed patients. Lancet Infect Dis. 2003;3:685-702.

42. Shah RD, Wunderink RG. Viral pneumonia and acute respiratory distress syndrome. Clin Chest Med. 2017;38:113-25.

43. Vakil E, Evans SE. Viral pneumonia in patients with hematologic malignancy or hematopoietic stem cell transplantation. Clin Chest Med. 2017;38:97-111.

44. Mikkelsen ME, Shah CV, Meyer NJ, Gaieski DF, Lyon S, Miltiades AN, Goyal M, Fuchs BD, Bellamy SL, Christie JD. The epidemiology of acute respiratory distress syndrome in patients presenting to the emergency department with severe sepsis. Shock. 2013;40:375-81.

45. Seethala RR, Blackney K, Hou P, Kaafarani HMA, Yeh DD, Aisiku I, Tainter C, deMoya M, King D, Lee $\mathrm{J}$. The association of age with short-term and longterm mortality in adults admitted to the intensive care unit. J Intensive Care Med. 2017;32:554-8.

46. Dhokarh R, Li G, Schmickl CN, Kashyap R, Assudani J, Limper AH, Gajic O. Drug-associated acute lung injury: a population-based cohort study. Chest. 2012;142:845-50.

47. Shannon V, Price K. Pulmonary complications of cancer therapy. Anesthesiol Clin North Am. 1998;16:563-85.

48. Ryu JH. Chemotherapy-induced pulmonary toxicity in lung cancer patients. J Thorac Oncol. 2010;5:1313-4.

49. Sadowska AM, Specenier P, Germonpre P, Peeters M. Antineoplastic therapy-induced pulmonary toxicity. Expert Rev Anticancer Ther. 2013;13:997-1006.

50. Gibelin A, Parrot A, Maitre B, Brun-Buisson C, Mekontso Dessap A, Fartoukh M, de Prost N. Acute respiratory distress syndrome mimickers lacking common risk factors of the Berlin definition. Intensive Care Med. 2016;42:164-72.

51. Mathes DD. Bleomycin and hyperoxia exposure in the operating room. Anesth Analg. 1995;8:624-9.

52. Couderc LJ, Stelianides S, Frachon I, Stern M, Epardeau B, Baumelou E, Caubarrere I, Hermine O. Pulmonary toxicity of chemotherapy and G/GMCSF: a report of five cases. Respir Med. 1999;93:65-8.

53. Goldiner PL, Schweizer O. The hazards of anesthesia and surgery in bleomycin-treated patients. Semin Oncol. 1979;6:121-4.

54. Forshag MS, Cooper AD Jr. Postoperative care of the thoracotomy patient. Clin Chest Med. 1992; 13:33-45.

55. Reilly JJ Jr. Benefits of aggressive perioperative management in patients undergoing thoracotomy. Chest. $1995 ; 107: 312 \mathrm{~s}-5 \mathrm{~s}$.

56. Hyde BR, Woodside KJ. Postoperative acute respiratory distress syndrome development in the thoracic surgery patient. Semin Thorac Cardiovasc Surg. 2006;18:28-34

57. Ahya VN. Noninfectious acute lung injury syndromes early after hematopoietic stem cell transplantation. Clin Chest Med. 2017;38:595-606.

58. Yadav H, Nolan ME, Bohman JK, Cartin-Ceba R, Peters SG, Hogan WJ, Gajic O, Kor DJ. Epidemiology of acute respiratory distress syndrome following hematopoietic stem cell transplantation. Crit Care Med. 2016;44:1082-90.

59. Looney MR, Gilliss BM, Matthay MA. Pathophysiology of transfusion-related acute lung injury. Curr Opin Hematol. 2010;17:418-23.

60. Looney MR, Roubinian N, Gajic O, Gropper MA, Hubmayr RD, Lowell CA, Bacchetti P, Wilson G, Koenigsberg M, Lee DC, Wu P, Grimes B, Norris PJ, Murphy EL, Gandhi MJ, Winters JL, Mair DC, Schuller RM, Hirschler NV, Rosen RS, Matthay MA, Toy P. Prospective study on the clinical course and outcomes in transfusion-related acute lung injury*. Crit Care Med. 2014;42:1676-87.

61. Vlaar AP, Binnekade JM, Prins D, van Stein D, Hofstra JJ, Schultz MJ, Juffermans NP. Risk factors and outcome of transfusion-related acute lung injury in the critically ill: a nested case-control study. Crit Care Med. 2010;38:771-8.

62. Rizk A, Gorson KC, Kenney L, Weinstein R. Transfusion-related acute lung injury after the infusion of IVIG. Transfusion. 2001;41:264-8.

63. Silliman CC, McLaughlin NJ. Transfusion-related acute lung injury. Blood Rev. 2006;20:139-59.

64. Vlaar AP, Juffermans NP. Transfusion-related acute lung injury: a clinical review. Lancet. 2013;382:984-94.

65. van Stein D, Beckers EA, Sintnicolaas K, Porcelijn L, Danovic F, Wollersheim JA, Brand A, van Rhenen DJ. Transfusion-related acute lung injury reports in the Netherlands: an observational study. Transfusion. 2010;50:213-20.

66. Eder AF. Improving safety for young blood donors. Transfus Med Rev. 2012;26:14-26.

67. Juffermans NP, Vlaar AP. Possible TRALI is a real entity. Transfusion. 2017;57:2539-41.

68. Marik PE, Sibbald WJ. Effect of stored-blood transfusion on oxygen delivery in patients with sepsis. JAMA. 1993;269:3024-9.

69. Walsh TS, McArdle F, McLellan SA, Maciver C, Maginnis M, Prescott RJ, McClelland DB. Does the storage time of transfused red blood cells influence regional or global indexes of tissue oxygenation in anemic critically ill patients? Crit Care Med. 2004;32:364-71.

70. Klein H, Natanson C, Flegel W. Transfusion of fresh vs. older red blood cells in the context of infection. ISBT Sci Ser. 2015;10:275-85.

71. Remy KE, Sun J, Wang D, Welsh J, Solomon SB, Klein HG, Natanson C, Cortes-Puch I. Transfusion of recently donated (fresh) red blood cells (RBCs) does not improve survival in comparison with current practice, while safety of the oldest stored units is yet to be 
established: a meta-analysis. Vox Sang. 2016;111:43-54.

72. Toy P, Gajic O, Bacchetti P, Looney MR, Gropper MA, Hubmayr R, Lowell CA, Norris PJ, Murphy EL, Weiskopf RB, Wilson G, Koenigsberg M, Lee D, Schuller R, Wu P, Grimes B, Gandhi MJ, Winters JL, Mair D, Hirschler N, Sanchez Rosen R, Matthay MA. Transfusion-related acute lung injury: incidence and risk factors. Blood. 2012;119:1757-67.

73. Wallis JP. Transfusion-related acute lung injury (TRALI) - under-diagnosed and under-reported. $\mathrm{Br}$ J Anaesth. 2003;90:573-6.

74. Looney MR, Gropper MA, Matthay MA. Transfusion-related acute lung injury: a review. Chest. 2004;126:249-58.

75. Lucas CE, Ledgerwood AM. Fresh frozen plasma/red blood cell resuscitation regimen that restores procoagulants without causing adult respiratory distress syndrome. J Trauma Acute Care Surg. 2012;72:821-7.

76. Lucas G, Win N, Calvert A, Green A, Griffin E, Bendukidze N, Hopkins M, Browne T, Poles A, Chapman C, Massey E. Reducing the incidence of TRALI in the UK: the results of screening for donor leucocyte antibodies and the development of national guidelines. Vox Sang. 2012;103:10-7.

77. Reesink HW, Lee J, Keller A, Dennington P, Pink J, Holdsworth R, Schennach H, Goldman M, Petraszko T, Sun J, Meng Y, Qian K, Rehacek V, Turek P, Krusius T, Juvonen E, Tiberghien P, Legrand D, Semana G, Muller JY, Bux J, Reil A, Lin CK, Daly H, McSweeney E, Porretti L, Greppi N, Rebulla P, Okazaki H, Sanchez-Guerrero SA, Baptista-Gonzalez HA, Martinez-Murillo C, Guerra-Marquez A, Rodriguez-Moyado H, Middelburg RA, Wiersum-Osselton JC, Brand A, van Tilburg C, Dinesh D, Dagger J, Dunn P, Brojer E, Letowska M, Maslanka K, Lachert E, Uhrynowska M, Zhiburt E, Palfi M, Berlin G, Frey BM, Puig Rovira L, Muniz-Diaz E, Castro E, Chapman C, Green A, Massey E, Win N, Williamson L, Silliman CC, Chaffin DJ, Ambruso DR, Blumberg N, Tomasulo P, Land KJ, Norris PJ, Illoh OC, Davey RJ, Benjamin RJ, Eder AF, McLaughlin L, Kleinman S, Panzer S. Measures to prevent transfusion-related acute lung injury (TRALI). Vox Sang. 2012;103:231-59.

78. Tynell E, Andersson TM, Norda R, Edgren G, Nyren O, Shanwell A, Reilly M. Should plasma from female donors be avoided? A populationbased cohort study of plasma recipients in Sweden from 1990 through 2002. Transfusion. 2010;50:1249-56.

79. Azoulay E, Fieux F, Moreau D, Thiery G, Rousselot P, Parrot A, Le Gall JR, Dombret H, Schlemmer B. Acute monocytic leukemia presenting as acute respiratory failure. Am J Respir Crit Care Med. 2003;167:1329-33.

80. Stucki A, Rivier AS, Gikic M, Monai N, Schapira M, Spertini O. Endothelial cell activation by myeloblasts: molecular mechanisms of leukostasis and leukemic cell dissemination. Blood. 2001;97:2121-9.

81. Porcu P, Danielson CF, Orazi A, Heerema NA, Gabig TG, McCarthy LJ. Therapeutic leukapheresis in hyperleucocytic leukaemias: lack of correlation between degree of cytoreduction and early mortality rate. Br J Haematol. 1997;98:433-6.

82. Tryka AF, Godleski JJ, Fanta CH. Leukemic cell lysis pneumonopathy. A complication of treated myeloblastic leukemia. Cancer. 1982;50:2763-70.

83. Fowler A, Hamman R, Good J, Benson K, Baird M, Eberle D, Petty T. Adult respiratory distress syndrome: risk with common predispositions. Ann Intern Med. 1983;98:593-7.

84. Hilbert G, Gruson D, Vargas F, Valentino R, GbikpiBenissan G, Dupon M, Reiffers J, Cardinaud JP. Noninvasive ventilation in immunosuppressed patients with pulmonary infiltrates, fever, and acute respiratory failure. N Engl J Med. 2001;344:481-7.

85. Azoulay E, Mokart D, Pene F, Lambert J, Kouatchet A, Mayaux J, Vincent F, Nyunga M, Bruneel F, Laisne LM, Rabbat A, Lebert C, Perez P, Chaize M, Renault A, Meert AP, Benoit D, Hamidfar R, Jourdain M, Darmon M, Schlemmer B, Chevret S, Lemiale V. Outcomes of critically ill patients with hematologic malignancies: prospective multicenter data from France and Belgium - a groupe de recherche respiratoire en reanimation onco-hematologique study. J Clin Oncol. 2013;31:2810-8.

86. Azoulay E, Schlemmer B. Diagnostic strategy in cancer patients with acute respiratory failure. Intensive Care Med. 2006;32:808-22.

87. Azoulay E, Thiery G, Chevret S, Moreau D, Darmon M, Bergeron A, Yang K, Meignin V, Ciroldi M, Le Gall JR, Tazi A, Schlemmer B. The prognosis of acute respiratory failure in critically ill cancer patients. Medicine (Baltimore). 2004;83:360-70.

88. de Montmollin E, Tandjaoui-Lambiotte Y, Legrand M, Lambert J, Mokart D, Kouatchet A, Lemiale V, Pene F, Bruneel F, Vincent F, Mayaux J, Chevret S, Azoulay E. Outcomes in critically ill cancer patients with septic shock of pulmonary origin. Shock. 2013;39:250-4.

89. Mokart D, Azoulay E, Schnell D, Bourmaud A, Kouatchet A, Pene F, Lemiale V, Lambert J, Bruneel F, Vincent F, Legrand M, Rabbat A, Darmon $M$. Acute respiratory failure in neutropenic patients is associated with a high post-ICU mortality. Minerva Anestesiol. 2013;79:1156-63.

90. Azoulay E, Alberti C, Bornstain C, Leleu G, Moreau D, Recher C, Chevret S, Le Gall JR, Brochard L, Schlemmer B. Improved survival in cancer patients requiring mechanical ventilatory support: impact of noninvasive mechanical ventilatory support. Crit Care Med. 2001;29:519-25.

91. Kraguljac AP, Croucher D, Christian M, Ibrahimova N, Kumar V, Jacob G, Kiss A, Minden MD, Mehta S. Outcomes and predictors of mortality 
for patients with acute leukemia admitted to the intensive care unit. Can Respir J. 2016;2016:3027656.

92. Price KJ, Thall PF, Kish SK, Shannon VR, Andersson BS. Prognostic indicators for blood and marrow transplant patients admitted to an intensive care unit. Am J Respir Crit Care Med. 1998;158:876-84.

93. Afessa B, Tefferi A, Hoagland HC, Letendre L, Peters SG. Outcome of recipients of bone marrow transplants who require intensive-care unit support. Mayo Clin Proc. 1992;67:117-22.

94. Suchyta MR, Orme JF Jr, Morris AH. The changing face of organ failure in ARDS. Chest. 2003;124:1871-9.

95. Mokart D, Lambert J, Schnell D, Fouche L, Rabbat A, Kouatchet A, Lemiale V, Vincent F, Lengline E, Bruneel F, Pene F, Chevret S, Azoulay E. Delayed intensive care unit admission is associated with increased mortality in patients with cancer with acute respiratory failure. Leuk Lymphoma. 2013;54:1724-9.

96. Brower RG, Matthay MA, Morris A, Schoenfeld D, Thompson BT, Wheeler A. Ventilation with lower tidal volumes as compared with traditional tidal volumes for acute lung injury and the acute respiratory distress syndrome. N Engl J Med. 2000;342:1301-8.

97. Peter JV, John P, Graham PL, Moran JL, George IA, Bersten A. Corticosteroids in the prevention and treatment of acute respiratory distress syndrome (ARDS) in adults: meta-analysis. BMJ. 2008;336:1006-9.

98. Brun-Buisson C, Brochard L. Corticosteroid therapy in acute respiratory distress syndrome: better late than never? JAMA. 1998;280:182-3.

99. Meduri GU, Headley AS, Golden E, Carson SJ, Umberger RA, Kelso T, Tolley EA. Effect of prolonged methylprednisolone therapy in unresolving acute respiratory distress syndrome: a randomized controlled trial. JAMA. 1998;280:159-65.

100. Tang BM, Craig JC, Eslick GD, Seppelt I, McLean AS. Use of corticosteroids in acute lung injury and acute respiratory distress syndrome: a systematic review and meta-analysis. Crit Care Med. 2009;37:1594-603.

101. Conner BD, Bernard GR. Acute respiratory distress syndrome. Potential pharmacologic interventions. Clin Chest Med. 2000;21:563-87.

102. Schuller D, Mitchell JP, Calandrino FS, Schuster DP. Fluid balance during pulmonary edema. Is fluid gain a marker or a cause of poor outcome? Chest. 1991;100:1068-75.

103. Schuster DP. Fluid management in ARDS: "keep them dry" or does it matter? Intensive Care Med. 1995;21:101-3.

104. Chang DW, Huynh R, Sandoval E, Han N, Coil CJ, Spellberg BJ. Volume of fluids administered during resuscitation for severe sepsis and septic shock and the development of the acute respiratory distress syndrome. J Crit Care. 2014;29:1011-5.

105. Cheng IW, Eisner MD, Thompson BT, Ware LB, Matthay MA. Acute effects of tidal volume strategy on hemodynamics, fluid balance, and sedation in acute lung injury. Crit Care Med. 2005;33:63-70; discussion 239-240

106. Krzak A, Pleva M, Napolitano LM. Nutrition therapy for ALI and ARDS. Crit Care Clin. 2011;27:647-59.

107. Ball J, Venn R. The 21st International Symposium on Intensive Care and Emergency Medicine, Brussels, Belgium, 20-23 March 2001. Crit Care. 2001;5:138-41.

108. Kramer N, Meyer TJ, Meharg J, Cece RD, Hill NS. Randomized, prospective trial of noninvasive positive pressure ventilation in acute respiratory failure. Am J Respir Crit Care Med. 1995;151:1799-806.

109. Bellani G, Laffey JG, Pham T, Madotto F, Fan E, Brochard L, Esteban A, Gattinoni L, Bumbasirevic V, Piquilloud L, van Haren F, Larsson A, McAuley DF, Bauer PR, Arabi YM, Ranieri M, Antonelli M, Rubenfeld GD, Thompson BT, Wrigge H, Slutsky AS, Pesenti A. Noninvasive ventilation of patients with acute respiratory distress syndrome. Insights from the LUNG SAFE study. Am J Respir Crit Care Med. 2017;195:67-77.

110. Depuydt PO, Soares M. Cancer patients with ARDS: survival gains and unanswered questions. Intensive Care Med. 2014;40:1168-70.

111. Tonetti T, Vasques F, Rapetti F, Maiolo G, Collino F, Romitti F, Camporota L, Cressoni M, Cadringher P, Quintel M, Gattinoni L. Driving pressure and mechanical power: new targets for VILI prevention. Ann Transl Med. 2017;5:286.

112. Cavalcanti AB, Suzumura EA, Laranjeira LN, Paisani DM, Damiani LP, Guimaraes HP, Romano ER, Regenga MM, Taniguchi LNT, Teixeira C, Pinheiro de Oliveira R, Machado FR, Diaz-Quijano FA, Filho MSA, Maia IS, Caser EB, Filho WO, Borges MC, Martins PA, Matsui M, Ospina-Tascon GA, Giancursi TS, Giraldo-Ramirez ND, Vieira SRR, Assef M, Hasan MS, Szczeklik W, Rios F, Amato MBP, Berwanger O, Ribeiro de Carvalho CR. Effect of lung recruitment and titrated positive end-expiratory pressure (PEEP) vs low PEEP on mortality in patients with acute respiratory distress syndrome: a randomized clinical trial. JAMA. 2017;318:1335-45.

113. Morelli A, Del Sorbo L, Pesenti A, Ranieri VM, Fan E. Extracorporeal carbon dioxide removal (ECCO2R) in patients with acute respiratory failure. Intensive Care Med. 2017;43:519-30.

114. Combes A, Hajage D, Capellier G, Demoule A, Lavoue S, Guervilly C, Da Silva D, Zafrani L, Tirot P, Veber B, Maury E, Levy B, Cohen Y, Richard C, Kalfon P, Bouadma L, Mehdaoui H, Beduneau G, Lebreton G, Brochard L, Ferguson ND, Fan E, Slutsky AS, Brodie D, Mercat A. Extracorporeal membrane oxygenation for severe acute respiratory distress syndrome. N Engl J Med. 2018;378:1965-75.

115. Raiker NK, Cajigas H. Early initiation of venovenous extracorporeal membrane oxygenation in a mechanically ventilated patient with severe acute respiratory distress syndrome. BMJ Case Rep. 2018; pii: bcr2018-226223. 
116. Gattinoni L, Carlesso E, Taccone P, Polli F, Guerin C, Mancebo J. Prone positioning improves survival in severe ARDS: a pathophysiologic review and individual patient meta-analysis. Minerva Anestesiol. 2010;76:448-54.

117. Sud S, Friedrich JO, Taccone P, Polli F, Adhikari NK, Latini R, Pesenti A, Guerin C, Mancebo J, Curley MA, Fernandez R, Chan MC, Beuret P, Voggenreiter G, Sud M, Tognoni G, Gattinoni L. Prone ventilation reduces mortality in patients with acute respiratory failure and severe hypoxemia: systematic review and meta-analysis. Intensive Care Med. 2010;36:585-99.

118. Gattinoni L, Protti A, Caironi P, Carlesso E. Ventilator-induced lung injury: the anatomical and physiological framework. Crit Care Med. 2010;38:S539-48.

119. Protti A, Andreis DT, Milesi M, Iapichino GE, Monti M, Comini B, Pugni P, Melis V, Santini A, Dondossola D, Gatti S, Lombardi L, Votta E, Carlesso E, Gattinoni L. Lung anatomy, energy load, and ventilator-induced lung injury. Intensive Care Med Exp. 2015;3:34.

120. Kamo T, Aoki Y, Fukuda T, Kurahashi K, Yasuda H, Sanui M, Nango E, Abe T, Lefor AK, Hashimoto $\mathrm{S}$. Optimal duration of prone positioning in patients with acute respiratory distress syndrome: a protocol for a systematic review and meta-regression analysis. BMJ Open. 2018;8:e021408.

121. Kim WY, Kang BJ, Chung CR, Park SH, Oh JY, Park SY, Cho WH, Sim YS, Cho YJ, Park S, Kim JH, Hong SB. Prone positioning before extracorporeal membrane oxygenation for severe acute respiratory distress syndrome: a retrospective multicenter study. Med Intensiva. 2018. pii: S0210-5691(18)30160-8.

122. Lucchini A, De Felippis C, Pelucchi G, Grasselli G, Patroniti N, Castagna L, Foti G, Pesenti A, Fumagalli R. Application of prone position in hypoxaemic patients supported by veno-venous ECMO. Intensive Crit Care Nurs. 2018;48:61-8.

123. Munshi L, Del Sorbo L, Adhikari NKJ, Hodgson CL, Wunsch H, Meade MO, Uleryk E, Mancebo J, Pesenti A, Ranieri VM, Fan E. Prone position for acute respiratory distress syndrome. A systematic review and meta-analysis. Ann Am Thorac Soc. 2017;14:S280-s288.

124. Ferguson ND, Cook DJ, Guyatt GH, Mehta S, Hand L, Austin P, Zhou Q, Matte A, Walter SD, Lamontagne F, Granton JT, Arabi YM, Arroliga AC, Stewart TE, Slutsky AS, Meade MO. High-frequency oscillation in early acute respiratory distress syndrome. N Engl J Med. 2013;368:795-805.

125. Young D, Lamb SE, Shah S, MacKenzie I, Tunnicliffe W, Lall R, Rowan K, Cuthbertson BH, Group OS. High-frequency oscillation for acute respiratory distress syndrome. $\mathrm{N}$ Engl $\mathrm{J}$ Med. 2013;368:806-13.

126. Ferguson ND. High-frequency oscillatory ventilation in adults: handle with care. Crit Care. 2014;18:464.

127. Goligher EC, Munshi L, Adhikari NKJ, Meade MO, Hodgson CL, Wunsch H, Uleryk E, Gajic O, Amato MPB, Ferguson ND, Rubenfeld GD, Fan E. Highfrequency oscillation for adult patients with acute respiratory distress syndrome. A systematic review and meta-analysis. Ann Am Thorac Soc. 2017;14: S289-s296.

128. Meade MO, Young D, Hanna S, Zhou Q, Bachman TE, Bollen C, Slutsky AS, Lamb SE, Adhikari NKJ, Mentzelopoulos SD, Cook DJ, Sud S, Brower RG, Thompson BT, Shah S, Stenzler A, Guyatt G, Ferguson ND. Severity of hypoxemia and effect of high-frequency oscillatory ventilation in acute respiratory distress syndrome. Am J Respir Crit Care Med. 2017;196:727-33.

129. Esnault P, Prunet B, Nguyen C, Forel JM, Guervilly C, Zhou Y, Kang Y. Early application of airway pressure release ventilation in acute respiratory distress syndrome: a therapy for all? Intensive Care Med. 2018;44:135-6.

130. Chatburn RL, Mireles-Cabodevila E. Closed-loop control of mechanical ventilation: description and classification of targeting schemes. Respir Care. 2011;56:85-102.

131. Slutsky AS. Neuromuscular blocking agents in ARDS. N Engl J Med. 2010;363:1176-80.

132. Alhazzani W, Alshahrani M, Jaeschke R, Forel JM, Papazian L, Sevransky J, Meade MO. Neuromuscular blocking agents in acute respiratory distress syndrome: a systematic review and meta-analysis of randomized controlled trials. Crit Care. 2013;17:R43.

133. Papazian L, Forel JM, Gacouin A, Penot-Ragon C, Perrin G, Loundou A, Jaber S, Arnal JM, Perez D, Seghboyan JM, Constantin JM, Courant P, Lefrant JY, Guerin C, Prat G, Morange S, Roch A. Neuromuscular blockers in early acute respiratory distress syndrome. N Engl J Med. 2010;363:1107-16.

134. Türkoğlu M, Erdem GU, Suyanı E, Sancar ME, Yalçın MM, Aygencel G, Akı Z, Sucak G. Acute respiratory distress syndrome in patients with hematological malignancies. Hematology. 2013;18(3):123-30. 